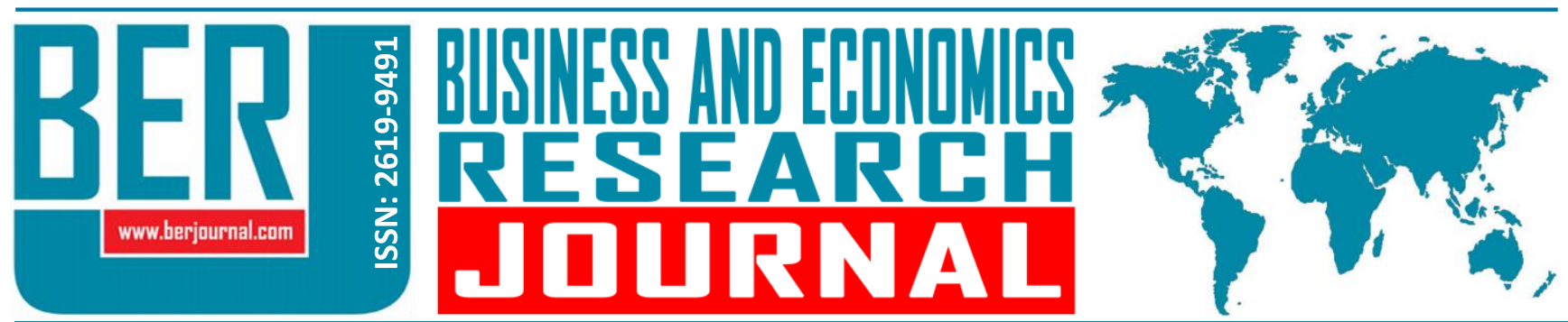

Business and Economics Research Journal Vol. 10, No. 4, 2019, pp. 789-806 doi: 10.20409/berj.2019.201

\section{Türkiye'de Yeni Politika Bileşiminin Finansal İstikrar ve Fiyat İstikrarı Üzerindeki Etkilerine İlişkin Bir Değerlendirme ${ }^{1}$}

\begin{abstract}
Ali Ilhan ${ }^{\mathrm{a}}$, Metin Ozdemir ${ }^{\mathrm{b}}$
Öz: Küresel finansal krizin ardından Türkiye gibi pek çok yükselen piyasa ekonomisinin fiyat istikrarı ile finansal istikrarın bir arada ele alınmasına imkan verecek politika çerçeveleri geliştirdiği görülmüştür. Gerek ortodoks enflasyon hedeflemesinin kriz ile gün yüzüne çıkan sorunları gerekse küresel sermaye akımlarındaki yön değiştirmelere esnek bir biçimde tepki verme gereği karşısında Türkiye Cumhuriyet Merkez Bankası Kasım 2010'dan itibaren yeni politika bileşimini uygulamaya başlamıştır. Bu çalış̧ada, Türkiye'de yeni politika bileșimi altında uygulanan politikaların değerlendirilmesi amaçlanmıștır. Yeni politika bileşimi çerçevesinde gerçekleştirilen para politikası ve makro ihtiyati politika uygulamaları incelendiğinde politikaların finansal istikrar doğrultusunda belirlenen ara hedeflere ulaşmada başarılı bir performans ortaya koyduğu görülmüştür. Diğer taraftan söz konusu başarının, politika otoritelerinin tek haneli faiz oranlarının kalıcı hale gelmesi ve büyümenin sürdürülmesi amacıyla- yeni politika bileşiminin içsel risklerini göz ardı etmelerine ve para politikasının normalleșmesi için atılması gereken adımları geciktirmelerine neden olduğu belirtilmelidir. Bununla birlikte makro ihtiyati politikanın büyüme amacı için de kullanımı, enflasyon oranının yükselmesi ve küresel politika ortamının farkılısşması sebebiyle büyümenin istikrarsız bir seyir izlemesine bağlı olarak politika açmazları yaratmıştır. Bu nedenle yeni politika bileşiminin finansal istikrarın sağlanması hususunda başarılı olduğu görülse de sadeleşmenin gecikmesi ve fiyat istikrarının sağlanamaması nedeniyle kendi başarısının kurbanı olduğunu belirtmek gerekmektedir.
\end{abstract}

\section{An Evaluation of the Effects of Turkey's New Policy Mix on Financial Stability and Price Stability}

Abstract: After the global financial crisis, it has been seen that many emerging markets like Turkey have developed policy frameworks that allow for price stability and financial stability taken together. The CBRT has implemented new policy mix since November 2010, in response to need to respond flexibly to the problems faced by orthodox inflation targeting and the changes in global capital flows. In this study, it is aimed to evaluate the policies implemented under new policy mix. Analyzing the monetary policy and macroprudential policy practices within the framework of new policy mix, it has seen that policies have shown a successful performance in achieving the intermediate targets that determined in line with financial stability. On the other hand, it should be noted that policymakers -to keep single digit interest rates permanent and sustain economic growth-ignored the internal risks of the new policy mix and delayed the steps that required for normalization of monetary policy. However, the use of macroprudential policy for the purpose of economic growth has created policy dilemmas due to an unstable course of economic growth that caused by to the rise in inflation rate and changing the global policy environment. Although the new policy mix has seen to be successful in achieving financial stability, it has to be stated that due to the delay in normalization and the lack of price stability make it a victim of its own success.
Anahtar Sözcükler: Finansal İstikrar, Fiyat İstikrarı, Makro Intiyati Politika, Para Politikası, Türkiye Ekonomisi

JEL: E52, E58, G18

$\begin{array}{ll}\text { Geliş } & : 05 \text { Mart } 2019 \\ \text { Düzeltme } & : \text { 26 Nisan } 2019 \\ \text { Kabul } & : 08 \text { Mayıs 2019 } \\ \text { Tür } & \text { : Araştırma }\end{array}$

Keywords: Financial Stability, Price Stability, Macroprudential Policy, Monetary Policy, Turkish Economy

JEL: E52, E58, G18

Received : 05 March 2019

Revised : 26 April 2019

Accepted : 08 May 2019

Type : Research

a Res. Asst., PhD., Tekirdag Namık Kemal University, Faculty of Economics and Administrative Sciences, Department of Economics, Tekirdag, Turkey, ailhan@nku.edu.tr (ORCID ID: 0000-0001-6201-5353)

b Assoc. Prof., PhD., Bursa Uludag University, Faculty of Economics and Administrative Sciences, Department of Economics, Bursa, Turkey, mozdemir@uludag.edu.tr (ORCID ID: 0000-0002-3944-4018) 


\section{Giriş}

Türkiye ekonomisi, küresel finansal kriz sonrası dönemde oluşan küresel likidite bolluğunun yol açtığı makro-finansal risklere yoğun bir şekilde maruz kalmıştır. Gelişmiş ülkelerin krizden çıkmak amacıyla uyguladıkları niceliksel genişleme (quantitative easing) politikaları neticesinde hızlanan sermaye girişleri, kredi kullanımını ivmelendirmiş ve Türk Lirasının ( $T L)$ değerlendiği bir dönemi de beraberinde getirmiştir. İç ve dış talep arasında giderek belirgin hale gelen ayrışma cari açığı ciddi bir biçimde olumsuz etkilemiştir. Söz konusu açığın finansmanının neredeyse tamamının kısa vadeli sermaye girişleri ile gerçekleştirilmesi, küresel risk iştahındaki ani değişimler karşısında ekonominin kırılganlığını arttırmıştır. Enflasyon hedeflemesine dayalı mevcut para politikası çerçevesinin sermaye girişlerinin neden olduğu politika açmazlarını çözümlemede yetersiz kalması, finansal istikrarın makro perspektiften ele alındığı esnek bir politika çerçevesi ihtiyacını ortaya çıkarmıştır. Bu doğrultuda kısa vadeli sermaye girişlerinin hızını yavaşlatmak ve kredi büyüme oranındaki aşııılıkları kontrol altına almak amacıyla Türkiye Cumhuriyet Merkez Bankası (TCMB) Kasım 2010' dan $^{2}$ itibaren yeni politika bileşimini uygulamaya başlamıştır.

Yeni politika bileşiminde finansal istikrar hedefi, fiyat istikrarı ile aynı seviyeye getirilirken para politikası makro ihtiyati politika ile birlikte yürütülmüştür. Para politikası stratejisinde, ortodoks enflasyon hedeflemesi gözden geçirilmiş ve destekleyici bir amaç olarak finansal istikrar benimsenmiştir. Fiyat istikrarı, nihai hedef olma özelliğini sürdürürken para politikasının kapsamı, küresel likidite koşullarının yol açtığı makro-finansal riskleri de dikkate alacak şekilde genişletilmiştir. Bu doğrultuda TCMB'nin araç seti, asimetrik faiz koridoru ${ }^{3}$ ve rezerv opsiyon mekanizması $(\mathrm{ROM})^{4}$ gibi yeni araçlarla çeşitlendirilmiş ve zorunlu karşlıklar gibi geleneksel araçlar makro ihtiyati hedeflere yönelik olarak kullanılmıştır.

TCMB'nin sahip olduğu araç seti ile belirlenen ara hedeflere ${ }^{5}$ ulaşmada yetersiz kaldığının görülmesi, finansal istikrarın sağlanmasından sorumlu diğer kurumların da yeni politika bileşiminde rol almasına neden olmuştur. Bu doğrultuda -başta Bankacilık Düzenleme ve Denetleme Kurumu (BDDK)- olmak üzere finansal düzenleyici ve denetleyici kurumlar, -Finansal İstikrar Komitesi'nin (FIK) rehberliği ve koordinatörlüğü altındaküresel likidite değişimlerinin ulusal ekonomi üzerindeki olumsuz etkilerini azaltmaya yönelik olarak TCMB'nin bireysel çabalarını destekleyici makro ihtiyati tedbirlerin tasarlayıcısı ve uygulayıcısı olmuşlardır.

Kasım 2010'dan itibaren TCMB öncülüğünde uygulanan yeni politika bileşimi, fiyat istikrarı ve finansal istikrar arasında belirgin değiş-tokuş (trade-off) ilişkileri doğurmuş ve makro ihtiyati politikanın finansal istikrar amacı yanında büyüme kaygıları ile de kullanıldığına tanık olunmuştur. Bu çalışmada, Türkiye'de yeni politika bileşimi altında uygulanan politikaların değerlendirilmesi amaçlanmıştır. Bu çerçevede, Kasım 2010 ile Aralık 2017 arası dönemde gerçekleştirilen para politikası ve makro ihtiyati politika uygulamalarının finansal istikrar ve fiyat istikrarı üzerindeki etkileri incelenmiştir.

Çalışmanın girişi izleyen bölümünde yeni politika bileşimi altında gerçekleştirilen para politikası ve makro ihtiyati politika uygulamaları açıklanmıştır. İzleyen iki bölümde sırasıyla politikaların finansal istikrar ve fiyat istikrarı üzerindeki etkileri değerlendirilmiştir. Çalışma, değerlendirmelere ilişkin sonuçlar ile tamamlanmıştır.

\section{Para Politikası ve Makro İhtiyati Politika Uygulamaları}

Yeni politika bileşiminin ilk ayağında, kısa vadeli sermaye girişlerinin yavaşlatılması ara hedef olarak benimsenmiştir. Bu doğrultuda TCMB ilk olarak enflasyon oranının hedeflenen düzeyin altında seyretmesinin de sağladığı alan ile geniş faiz koridoru ve düşük politika faizi araçlarının kullanımına yönelmiştir. Faiz koridoru aşağı yönlü genişletilerek gecelik piyasada oluşan faizlerin politika faizinden daha düşük seviyede oluşmasına ve dalgalı seyir izlemesine izin verilmiştir. Böylelikle, gecelik piyasa faizlerinin ortalama getirilerini düşürmek ve oynaklığını artırmak suretiyle spekülatif sermaye girişleri azaltılmaya çalışılmıştır (TCMB, 2011c: 3; Başçı ve Kara, 2011: 13).

Politika bileşiminin ikinci ayağında ise cari işlemler açığındaki artışın temel sebeplerinden biri olarak görülen kredi hacmindeki genişlemenin sınırlandırılması ara hedefi doğrultusunda zorunlu karşılıklar makro ihtiyati bir politika aracı olarak kullanılmıştır. Bu amaca yönelik olarak, zorunlu karşılıkların kapsamı 
genişletilmiş ve zorunlu karşılık oranları vadeye ve para birimine göre farklılaştırılarak kademeli bir şekilde yükseltilmiştir (TCMB, 2010: 22; 2011a: 12-13). Buna karşın bankaların, yükselen zorunlu karşılık oranlarının kredi arzını azaltıcı etkilerini hafifletmek amacıyla kar marjlarından belirli oranda feragat etmeleri ve TCMB'den açık piyasa işlemleri vasıtasıyla borçlanmaları, kredi büyüme hızındaki artışın sürmesine neden olmuştur (IMF, 2017: 69).

TCMB tarafından alınan tedbirlerin kredi büyüme hızını yavaşlatmada yetersiz kalması, yeni politika bileşiminin etkinliğinin artırılmasında finansal istikrardan sorumlu diğer kurumlara ihtiyaç duyulmasına yol açmıştır. FiK'in koordinatörlüğü altında ilk sıkılaştırıcı makro ihtiyati tedbirler BDDK tarafından Haziran 2011 'de uygulamaya konmuştur. Tüketici kredileri içerisinde büyüme oranı en yüksek olan ihtiyaç kredileri için bankaların yükümlü olduğu karşııık oranları arttırılmıştır. Tüketici kredilerinin uzun vadede yol açabileceği muhtemel riskleri azaltabilmek amacıyla sermaye yeterliliği hesaplamalarındaki risk ağırlıkları ihtiyaç kredileri için yükseltilmiştir. Bunun yanı sıra kredi kartlarının nakit kullanımına ilişkin düzenleme yine bu dönemde uygulanmaya başlanmıştır.

2011'in ikinci yarısından itibaren küresel büyümeye ve Euro bölgesindeki kamu borcunun sürdürülebilirliğine ilişkin kaygıların artması gelişmekte olan ülkelere benzer şekilde Türkiye'den de kayda değer sermaye çıkışlarının yaşanmasına neden olmuştur. TL'de yaşanan değer kayıplarının arzu edilen düzeyin üzerine çıkması karşısında TCMB, faiz koridorunu ve aktif likidite araçlarını sermaye girişlerinin hızlandığı dönemin tersi yönde kullanmaya başlamıştır. Daraltılan faiz koridoru ile kısa vadeli faizlerin oynaklığı azaltııırken döviz satış ihaleleriyle dış finansmandaki ani duruş (sudden stop) riski sınırlandırımaya çalışılmıştır (Kara, 2012: 27; TCMB, 2011b: 5-13).

Faiz koridoru ve aktif likidite yönetimi ile döviz kurundaki dalgalanmalar azaltılmasına karşın TL'deki sert değer kayıplarını engellemede başarılı olunamamıştır. Bununla birlikte işlenmemiş gıda fiyatlarındaki keskin artışlar ve yönetilen/yönlendirilen ürünlere öngörülenin üzerinde yapılan zamlar neticesinde orta vadeli enflasyon bekleyişlerindeki bozulma riski yükselmiştir (Aktaş ve Cortuk, 2012: 202).

TCMB, hızlanan enflasyon karşısında Ekim 2011'de parasal sıkılaştırmaya başlamıştır. Bu doğrultuda borç alma faizi sabit tutulurken borç verme faizi 350 baz puan artırılarak \%12,5'e çıkartılmışır. Likidite koşullarının sıkılaştıııarak fonlamanın daha yüksek maliyetli araçlara kaydırılması neticesinde Grafik 1'den de görüleceği üzere, gecelik piyasada oluşan faizlerde ve ağırlıklı ortalama fonlama maliyetinde (AOFM) belirgin bir yükseliş gerçekleşmiştir.

Grafik 1. Faiz Oranları: Kasım 2010-Nisan 2013

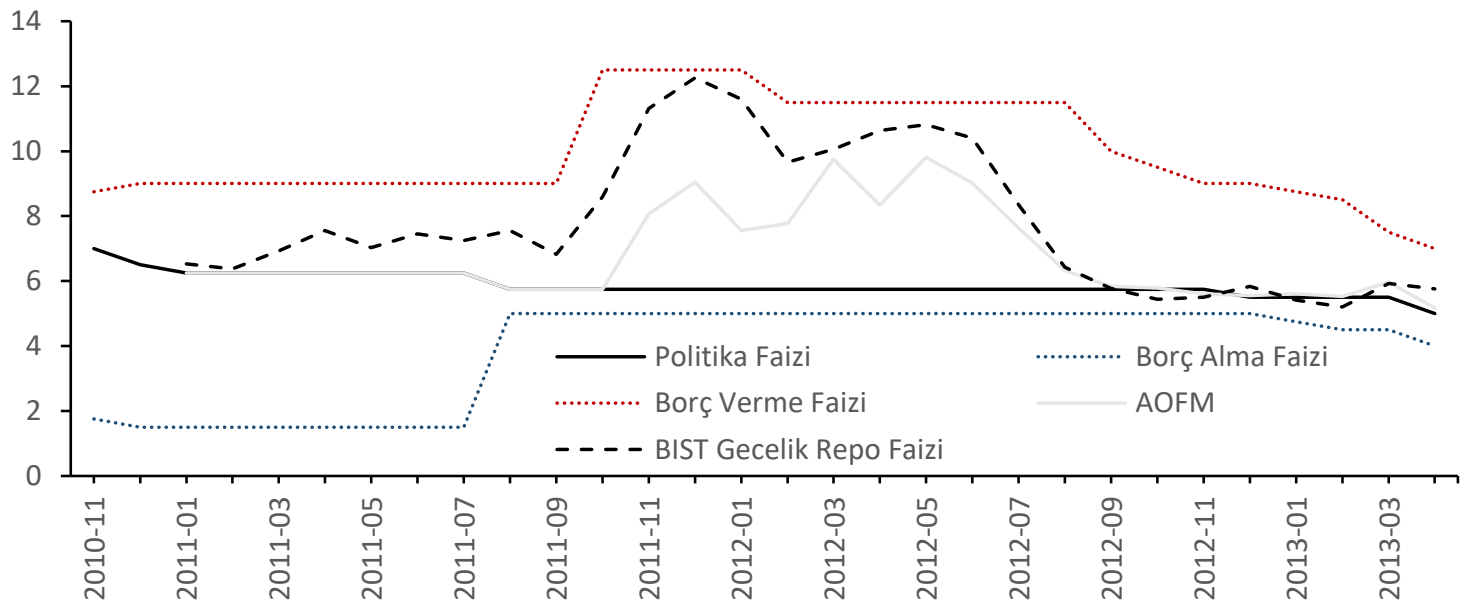

Kaynak: TCMB 
2011 yılsonu enflasyon oranının \%10.45 olarak gerçekleşmesine bağlı olarak 2012 yılının ilk yarısında $\mathrm{TCMB}$, temkinli bir para politikası duruşu sergilemiştir. Yılın ikinci yarısından itibaren küresel risk iştahının artması ve gelişmiş ülke merkez bankalarının ek parasal genişlemeleri ile birlikte sermaye girişlerinde ortaya çıkan hızlanma riski karşısında faiz indirimlerine gidilmiştir. Bu doğrultuda Eylül 2012-Mayıs 2013 döneminde koridorun üst bandı $\% 11,5^{\prime}$ den $\% 6,5^{\prime}$ e, alt bandı $\% 5^{\prime}$ den $\% 3,5^{\prime}$ e politika faizi de $\% 5,75^{\prime}$ den $\% 4,5^{\prime}$ e indirilmiştir (TCMB, 2013: 31-32).

Sermaye hareketlerindeki dalgalanmalara bağlı olarak ani duruş riskini göz önünde bulunduran TCMB, bankaların likidite yönetimlerine esneklik kazandırabilmek ve brüt döviz ile altın rezervlerini güçlendirebilmek amacıyla Eylül 2011'de uygulanmaya başlanan ROM'u Haziran 2012'den itibaren daha aktif bir şekilde kullanmayı tercih etmiştir. Bu doğrultuda, bankaların döviz ve altın şeklinde tutabilecekleri TL zorunlu karşılıklar için tesis dilimleri ve rezerv opsiyon katsayıları (ROK) kademeli bir şekilde yükseltilmiştir (TCMB, 2012b: 12-13).

Sermaye girişlerinin 2013'ün ilk aylarında da aynı hızda sürmesine bağlı olarak genişleyen kredi hacmi ve TL üzerindeki değerlenme baskısı karşısında TCMB, bir taraftan kısa vadeli faizleri düşük tutmaya çalışırken diğer taraftan zorunlu karşılıklar üzerinden sıkı makro ihtiyati politika duruşunu devam ettirmiştir. OcakMayıs 2013 döneminde politika faizi \%5'den \%3,5'e düşürülürken ROM'un etkin çalışan otomatik dengeleyici fonksiyonunun geniş bant belirsizliği ihtiyacını azaltması neticesinde borç alma faizinde 100 baz puan, borç verme faizinde ise 250 baz puan indirim gerçekleştirilerek faiz koridoru daraltılmıştır. Öte yandan yine aynı dönemde, bankaların yüksek borçlanmalarından kaynaklanabilecek riskleri sınırlamak amacıyla aşırı kaldıraçla çalışan bankalara ilave zorunlu karşılık yükü getiren kaldıraca dayalı zorunlu karşılık sistemi konjonktür karşıtı makro ihtiyati bir araç olarak uygulamaya konmuştur. Bankacılık sektöründeki yükümlülüklerin vade yapılarını daha sağlıklı hale getirmek amacıyla kısa vadeli yükümlülükler için TL ve yabancı para (YP) zorunlu karşılık oranları ölçülü bir şekilde artırılmıştır (TCMB, 2012b: 28-29; 2014a: 30-39).

Mayıs 2013'de FED'in "taper talk"6 açıklamasına bağlı olarak küresel piyasalarda para politikalarının sıkılaşacağına ilişkin bekleyişlerin güçlenmesi birçok gelişmekte olan ülkeye benzer şekilde Türkiye' den de ani sermaye çıkışlarının yaşanmasına neden olmuştur. TL'de gerçekleşen değer kayıplarının enflasyona ilişkin yukarı yönlü riskleri artırmasına karşın TCMB bu dönemde önceliği büyümeye vermiş ve politika faizini kullanmamıştır. Bunun yerine faiz koridorunun genişliğini değiştirerek ve likidite operasyonları gerçekleştirerek piyasa faizlerini etkilemeye çalışmıştır.

2013'ün ikinci yarısındaki sorunlar TL'deki değer kayıpları ile sınırlı kalmamıştır. 2012'nin son çeyreğinde \%15'lere kadar gerileyen toplam kredi büyüme oranı, kredi faizlerinin düşük seyrine bağlı olarak tüketici ve ticari kredi hacminde gerçekleşen artışla 2013'ün son çeyreğinde \%25'lere kadar yükselmiştir. Kredi büyüme oranının makul kabul edilebilecek düzeyin üzerine çıkması karşısında BDDK öncülüğünde ağılıklı olarak tüketici kredileri ve bireysel kredi kartlarına yönelik tedbirleri içeren ikinci makro ihtiyati sıkılaştırma paketi devreye sokulmuştur. Bu doğrultuda, tüketici kredilerinin ve bireysel kredi kartlarının risk ağırlıkları yükseltilmiştir. Gayrimenkul ve konut dışındaki tüketici kredilerinde vade sınırlamaları artırılmıştır. Genel karşılık kapsamına dahil edilen taşıt kredilerine, nihai fatura değerlerine bağlı olarak değişen oranda kredi-teminat tavanı getirilmiştir. Kredi kart limitlerine borç-gelir tavanı uygulanmış, bir takvim yılı içerisinde asgari ödeme miktarı üç kez ödenmeyen kredi kartları nakit kullanımına kapatılmıştır. Kredi kartlarında taksit süreleri sınırlandırılmış ve bazı harcama kalemlerinde taksit uygulaması sonlandırılmıştır. Bankacılık sektörü dışındaki sektörlerde hızlanan kredi büyümesini sınırlamak ve kredi kanallarını takip edebilmek amacıyla finansman şirketleri hem genel karşılık hem de zorunlu karşılık uygulamasına tabi tutulmuştur.

2013 yılının ikinci yarısından itibaren artan politik belirsizlikler ve Aralık ayında FED'in tahvil alımlarını azaltmaya başlaması, finansal piyasalardaki dalgalanmaların artmasına, TL'deki değer kaybının ve piyasa faizlerinin yükselmesine yol açmışır. Döviz kurunda ve risk primlerinde gerçekleşen yukarı yönlü hareketlere daha fazla kayıtsız kalamayan TCMB, Ocak 2014'de sert faiz artırımları gerçekleştirmiştir. Grafik 2'den de görüleceği üzere 550 baz puan arttırılan politika faizi \%10'a yükseltilirken koridorun alt bandı \%3,5'den \%8'e üst bandı ise $\% 7,75$ 'den $\% 12$ 'ye çıkarılmıştır. Bunun yanı sıra para politikasının operasyonel çerçevesini 
sadeleştirme amacıyla fonlamanın politika faizinden yapılacağı ilan edilmiş ve AOFM, bir hafta vadeli repo faizine yakın tutulmuştur (TCMB, 2015a: 28-36; IMF, 2017: 67).

Grafik 2. Faiz Oranları: Mayıs 2013-Ağustos 2016

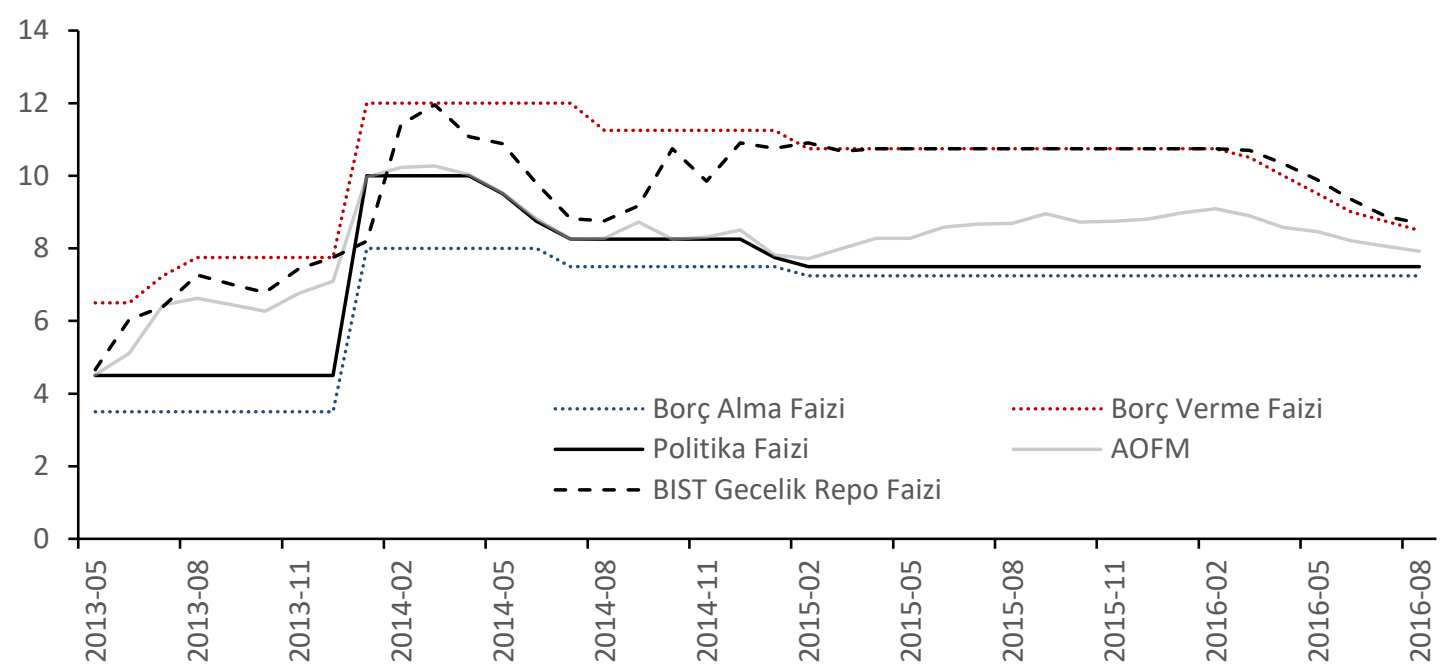

Kaynak: TCMB

Kredi büyümesini kontrol altına almaya yönelik mevcut makro ihtiyati politika uygulamalarının sürdürüldüğü bu dönemde, önceki dönemlerden farklı olarak kesit boyutundaki sistemik risklere ${ }^{7}$ verilen önem de artırılmıştır. Küresel finansal kriz sonrasında bankaların kredi büyümelerini büyük oranda mevduat dışı kaynaklarla finanse etmelerine bağlı olarak çekirdek dışı yükümlülüklerin toplam kaynaklar içerisindeki payının artması ve vadelerinin kısalması karşısında zorunlu karşılıklar çekirdek yükümlülükleri teşvik eden yapısal bir makro ihtiyati araç olarak kullanılmıştır (Kara, 2016: 132-133). Bu doğrultuda Kasım 2014'den itibaren bankaların ve finansman şirketlerinin TL olarak tesis ettikleri zorunlu karşılıklar için fonlama kalitesi ile orantılı şekilde faiz ödemesine başlanmış ve ödenecek faiz oranları 2015 yılı boyunca kademeli bir şekilde yükseltilmiştir ${ }^{8}$ (TCMB, 2014c: 14). Bunun yanı sıra uzun vadeli borçlanmayı teşvik etmek için çekirdek dışı kısa vadeli YP yükümlülükler için uygulanan zorunlu karşılık oranları kademeli olarak artırılmıştır (TCMB, 2015b: 43). YP yükümlülüklere uygulanan zorunlu karşılık oranlarındaki artışın döviz piyasasında dalgalanmalara yol açmasını engellemek amacıyla ROM'da çeşitli ayarlamalar yapıımıştır.

Küresel ekonomide ılımlı bir toparlanma sürecinin gerçekleşeceğine ilişkin beklentilerin güçlenmesi ve FED'in Aralık 2015'deki politika faizi artışının 25 baz puanda kalması, 2016'nın başından itibaren sermaye girişlerini yeniden hızlandırmış ve risk primlerini düşürmüştür. Bunun yanı sıra söz konusu dönemde kredi büyümesini kontrol altında tutan sıkı makro ihtiyati politika duruşu, BDDK tedbirleri ile güçlendirilmiştir. Bankaların likidite karşılama oranları artırıırken çekirdek sermaye gereksinimlerini karşılama düzeyleri dikkate alınarak kar dağıtım oranları sınırlandırılmıştır. Bankalara, hesaplanan kredi/GSYiH açığına bağı olarak konjonktür karşıtı sermaye tamponu bulundurma yükümlülüğü getirilmiştir.

2016 yılının ikinci yarısında ekonominin bir dizi olumsuz iç ve dış şoka maruz kalması, zayıflayan büyüme performansının yılın ikinci yarısında daha da kötüleşmesine neden olmuştur. TCMB'nin Mart ayından itibaren gerçekleştirdiği faiz indirimlerini zorunlu karşılıklarla da desteklemesine karşın büyümenin katalizörü olan krediler üzerinde beklenen sonuçlar alınamamıştır. Kredi büyüme hızındaki yavaşlamanın arzu edilen düzeyin ötesine geçmesi sonucunda Eylül 2016'da makro ihtiyati politika duruşu gevşetilmiştir. Bu doğrultuda, tüketici kredilerindeki büyümeyi sınırlama amacıyla BDDK'nın almış olduğu çok sayıdaki makro intiyati tedbir gevşetilmiş veya yürürlükten kaldırılmıştır.

2016 'nın son çeyreğinde uluslararası finansal görünüme ilişkin belirsizliğin artması ve ABD tahvil faizlerinin yükselmesi, portföy çıkışlarının hızlanmasına neden olmuştur (TCMB, 2016: 1-2). TL'deki değer 
kayıplarının fiyatlama davranışları ve enflasyonist beklentiler üzerinde olumsuz etkileri karşısında TCMB, Kasım 2016'da ölçülü bir parasal sıkılaştırmaya gitmiştir. FED'in 2016'daki faiz artırımı ile döviz kurunun yükselişini sürdürmesi ve enflasyona ilişkin yukarı yönlü riskleri artırması, TCMB'yi Ocak-Nisan 2017 döneminde öncekinden daha güçlü bir parasal sıkılaştırmaya mecbur bırakmıştır.

Bununla birlikte, kurdaki yükselişin geçici olarak görülmesi ve iktisadi faaliyetteki toparlanma eğiliminin devam ettirilmesi amacı, TCMB'nin likidite politikasını değiştirmesine neden olmuştur. Buna göre, öncelikle 1 hafta vadeli repo ile fonlamaya son verilmiş ve gecelik fonlama miktarı kademeli şekilde düşürülmüştür. Bankalar fonlama için gün sonuna yönlendirilerek fonlamanın büyük bir kısmı geç likidite penceresinden (GLP) sağlanmıştır ${ }^{9}$ (TCMB, 2017: 3). Ardından Grafik 3'den de görüleceği gibi GLP kapsamında borç verme faizi \%10'dan \%11'e çıkarılmıştır. 2017'nin ilk yarısında TL'deki değer kaybının gecikmeli etkileri ve yılın ikinci yarısında yurt içi talep artışı nedeniyle yükselen enflasyon neticesinde para politikası duruşunun sıkılaştırma derecesi artırılmış ve borç verme faizi Mart-Aralık döneminde $\% 12,75^{\prime}$ e yükseltilmiştir (TCMB, 2018: 13).

Grafik 3. Faiz Oranları: Eylül 2016-Aralık 2017

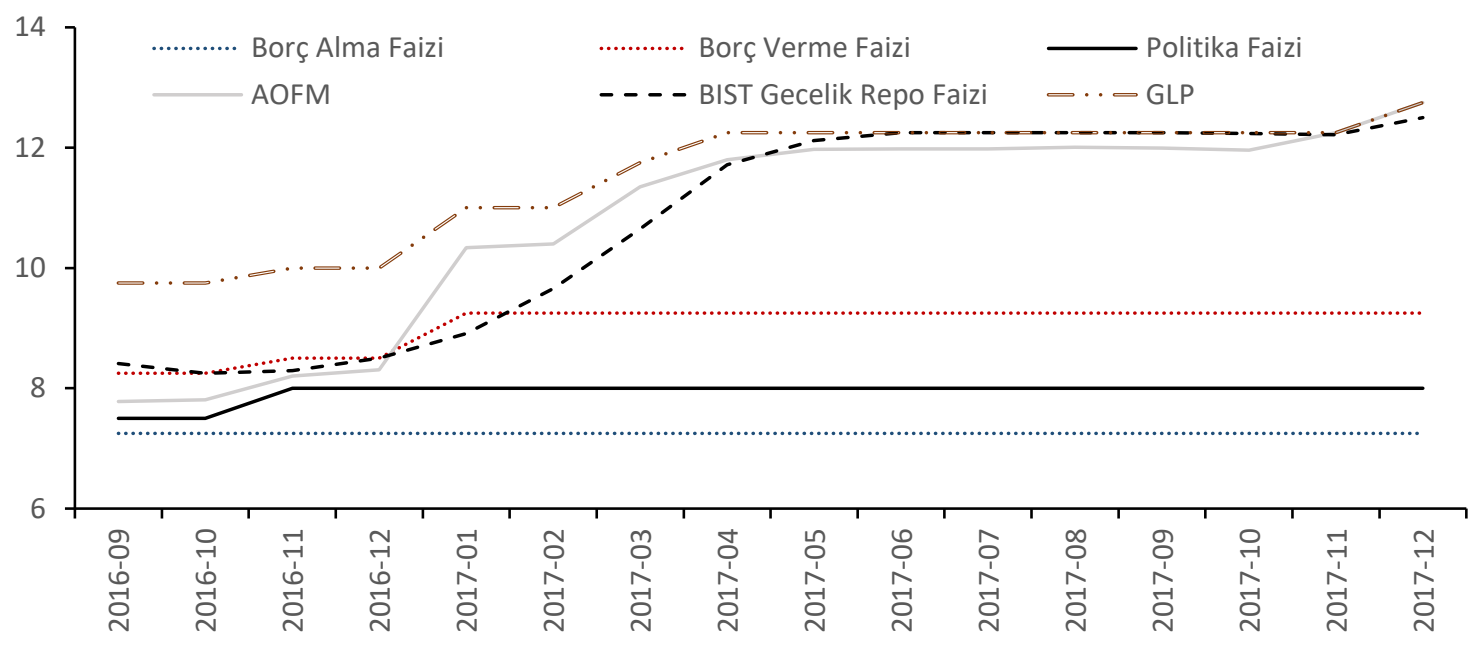

Kaynak: TCMB

2017 yılında bir yandan sıkı para politikası duruşuna devam edilirken diğer yandan kredi büyümesindeki canlanmayı desteklemek amacıyla gevşek makro intiyati politika duruşu sürdürülmüştür. Tüketici kredilerindeki büyümeyi artırmak için gevşetilen makro intiyati tedbirlerin yanı sıra ticari kredi hacmini desteklemek amacıyla Kredi Garanti Fonu (KGF) ${ }^{10}$ teşvikleri yükseltilmiştir. KGF'nin sağladığı kefalet miktarı, Hazine'nin desteği ile birlikte 2017 yılında 20 milyar TL'den 250 milyar TL'ye çıkarılmıştır (IMF, 2018: 5).

\section{Yeni Politika Bileşimi ve Finansal İstikrar}

TCMB'nin yeni politika bileşimini uygulamaya koymasında etkili olan cari açığa bağlı olarak biriken makro-finansal risklerin kontrol altına alınması ve finansal istikrarın sağlanması amacını, sadece krizin ardından oluşan küresel makroekonomik koşulların bir gereği olarak değerlendirmemek gerekmektedir. Bu anlamda, tarihsel olarak en düşük seviyelere gelen faiz oranlarını tek haneli düzeylerde kalıcı olarak sürdürme arzusunun ve böylelikle büyüme için uygun bir politika ortamının korunmasının yeni politika bileşiminin uygulanmasında önemli rol oynadığı vurgulanmalıdır.

Yeni politika bileşimi çerçevesinde finansal istikrarı sağlamaya yönelik gerçekleştirilen politika uygulamalarında belirlenen ara hedefler esas alınmakla birlikte politikaların finansal istikrara katkılarının ara hedefler ile sınırlı kalmadığını belirtmek gerekmektedir. 


\subsection{Cari İşlemler Bilançosu Üzerindeki Etkiler}

Küresel finansal kriz öncesi dönemin temel sorunlarından olan mali baskınlık olgusunun, krizin ardından yerini dışsal baskınlık problemine bıraktığı görülmüştür. ${ }^{11}$ Krizin ardından gelişmiş ülkelerin uyguladıkları geleneksel olmayan para politikalarına bağlı olarak artan sermaye girişleri, büyüme ve cari açık arasındaki ilişkinin giderek kuvvetlenmesine yol açmıştır. Bu doğrultuda, yeni politika bileşiminde küresel risk iştahındaki değişmelere bağlı olarak doğabilecek dışsal baskınlık sorunu karşısında proaktif bir duruş sergilendiğini söylemek mümkündür.

Yeni politika bileşiminin küresel finansal krizin ardından cari açıkta yaşanan sıçramayı kontrol altına almada kısmi bir başarı yakaladığını söylemek mümkündür. Grafik 4'te de görüleceği üzere 2011'in ilk çeyreğinde \%11,4 düzeyine ulaşan cari açığın 2016'nın üçüncü çeyreğinde -\%0,8'e kadar düştüğü gözlenmiştir.

Grafik 4. Büyüme ve Cari Açık: 2010-2017

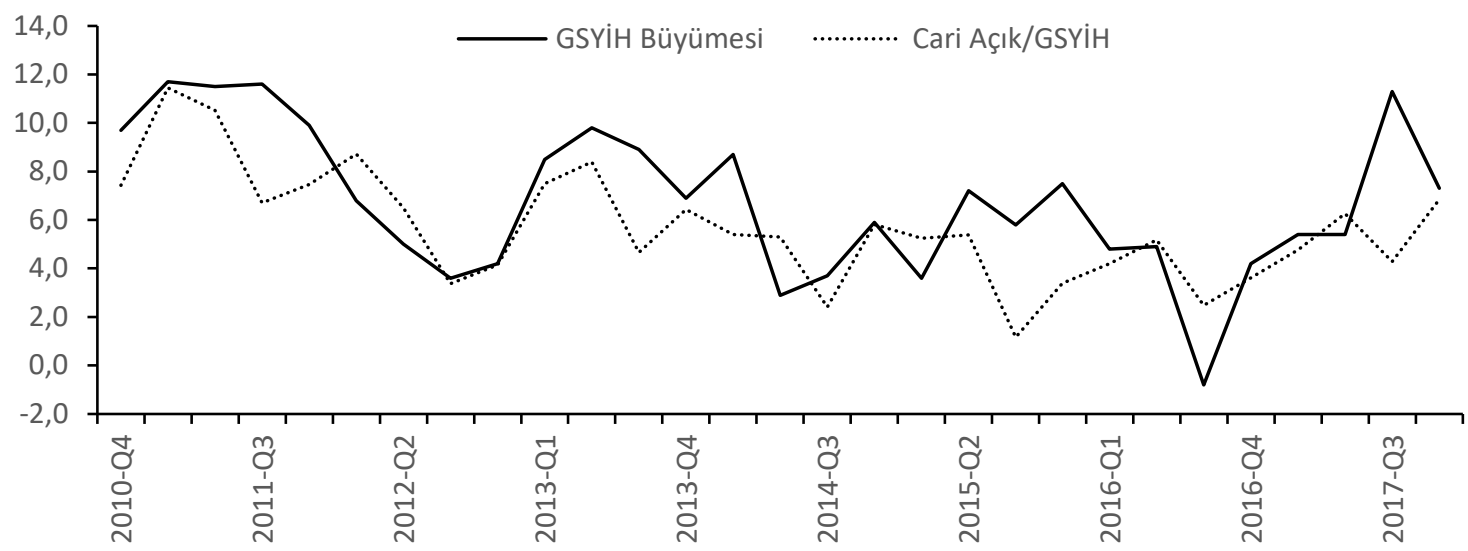

Not: Harcama yöntemiyle reel GSYiH (Zincirlenmiş hacim 2009=100).

Kaynak: TÜik ve TCMB

Cari işlemler dengesindeki iyileşmede para politikası duruşunun ve makro ihtiyati tedbirlerin önemli rol oynadığını ifade etmek mümkündür. Asimetrik faiz koridoru ile yaratılan yapıcı belirsizlik ve ROM'un otomatik dengeleyici fonksiyonu yoğun sermaye girişlerini yavaşlatmada etkili olmuştur. Küresel likidite bolluğunun yaşandığı dönemlerde faiz koridorunun aşağı yönlü genişletilmesi ve ROK'larda yapılan yukarı yönlü ayarlamalar sermaye girişlerinin hızını yavaşlatmıştır. Kredi büyümesini sınırlamaya yönelik makro intiyati tedbirler ile dış finansmana olan ihtiyaç azaltılmış ve ithal mal talebi baskılanmıştır. Bununla birlikte 2013 yııının sonlarından itibaren FED'in tahvil alım programını kademeli bir şekilde sonlandırmaya başlamasının yanı sıra emtia ve petrol fiyatlarındaki düşüşün iç ve dış talep arasındaki dengelenme sürecine sağladığı katkıları göz ardı etmemek gerekmektedir.

Cari açığın finansman kalitesine bakıldığında politika uygulamalarının olumlu sonuçlar verdiği görülmektedir. Portföy girişlerinin sermaye girişleri içerisindeki payında -son dönem haricinde- kayda değer bir azalış gerçekleşirken doğrudan yatırımların payı yeniden yükselmiştir (Grafik 5).

Bu azalışta etkili olan faktörlerin başında TCMB'nin zorunlu karşııklar üzerinden aldığı makro ihtiyati tedbirler gelmektedir. Zorunlu karşılık oranlarının vadeye göre farklılaştırılması ve YP zorunlu karşılık oranlarıın konjonktür karşıtı bir şekilde ayarlanması kısa vadeli kaynak kullanımını frenlemiş ve vade uyumsuzluğunu azaltmıştır. Bunun yanı sıra çekirdek dışı kısa vadeli YP yükümlülüklerdeki zorunlu karşılık oranlarının arttırılması da fonlama kalitesinin yükselmesine katkı sağlamıştır. 
Grafik 5. Cari Açık ve Finansmanı: Kasım 2010-Aralık2017

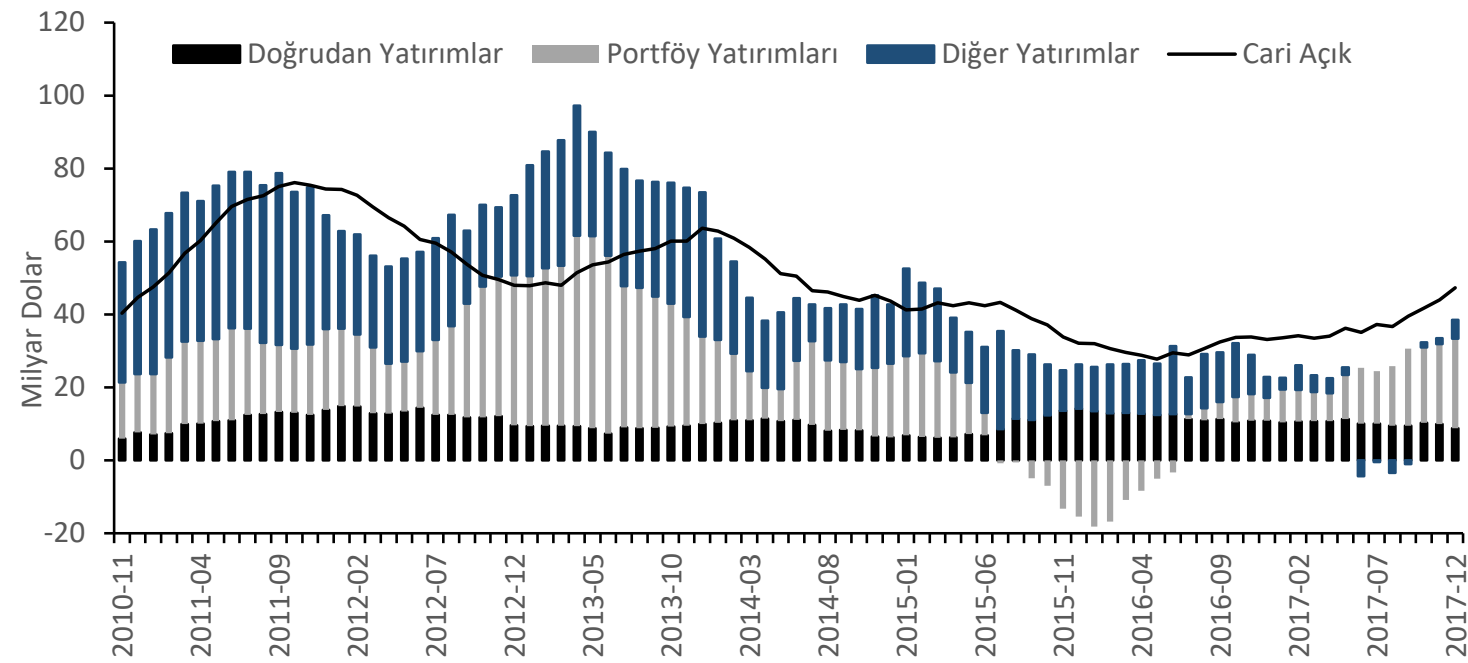

Not: Serilerin hareketli toplamları alınmıştır. Doğrudan yatırımlar, portföy yatırımları ve diğer yatırımlar net yükümlülüklerin net varlıklardan çıkarılmasıyla elde edilmiştir.

Kaynak: TCMB

\subsection{Kredi Hacmi Üzerindeki Etkiler}

Gelişmekte olan ekonomilerde sermaye hareketlerinin etkilerini güçlendiren mekanizmaların başında sermaye girişleri ile krediler arasındaki karşılıklı etkileşim gelmektedir. Bu ekonomilerde kredi büyümesi, finansal reformlar ve toplam faktör verimliliği artışından ziyade sermaye girişlerinin yoğunlaşmasından sonra hızlanmaktadır (Mendoza ve Terrones, 2008; Elekdağ ve Wu, 2011). Grafik 6'da, bu mekanizmanın Türkiye için de etkin bir şekilde çalıştığı görülmektedir. Küresel likidite bolluğunun yaşandığı dönemlerde sermaye hareketleri ve kredi büyümesi -belirli bir gecikmeyle- aynı yönde hareket etmişlerdir.

Grafik 6. Net Sermaye Hareketleri ve Toplam Kredi Büyüme Oranı: Kasım 2010-Aralık 2017

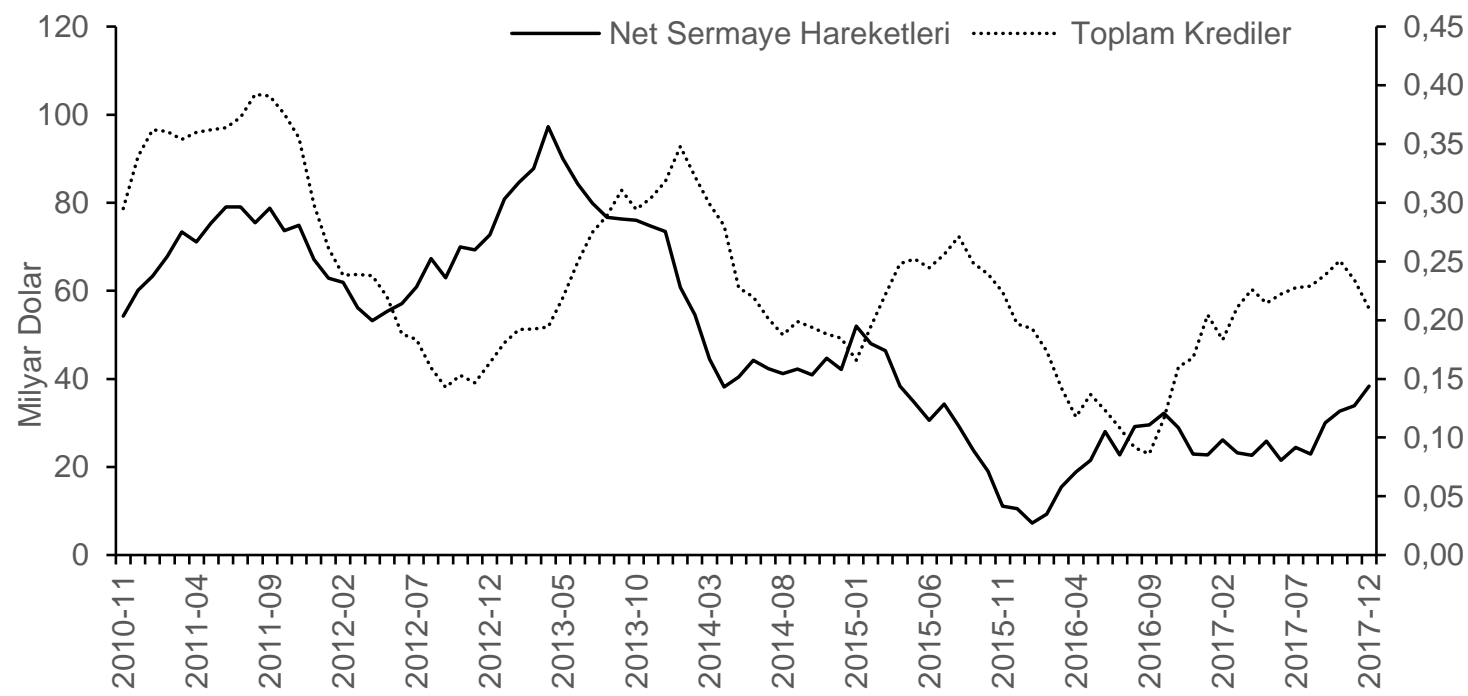

Not: Doğrudan yatırımlar, portföy yatırımları ve diğer yatırımların kümülatif değerlerinin toplanması ile elde edilen net sermaye hareketleri sol eksende gösterilmiştir. Sağ eksende gösterilen toplam kredi büyüme oranı ise öncelikle mevsimsellikten arındırılmış ardından yıllık yüzde değişimi hesaplanmıştır.

Kaynak: TCMB ve BDDK 
Yeni politika bileşiminde kredi büyümesini sınırlamaya yönelik ilk çabalar TCMB öncülüğünde zorunlu karşılık politikaları ile gerçekleşmiştir. Buna karşın zorunlu karşıııların kredi arz ve talebi üzerinde dolaylı etkilere sahip olması kredi büyümesinin arzu edilen seviyelere getirilememesine neden olmuştur. Zorunlu karşılık oranlarındaki sert artırımlara rağmen kredi büyüme oranının artmaya devam etmesi karşısında Fik koordinatörlüğünde makro intiyati tedbirler devreye sokulmuştur.

Haziran 2011' de birçoğu BDDK tarafından alınan tedbirleri içeren ilk makro ihtiyati sıkılaştırma paketi ile kredi büyüme hızı yavaşlatılmıştır. Bununla birlikte 2011'in ikinci yarısından itibaren etkisini giderek hissettiren Euro borç krizine bağlı olarak yaşanan sermaye çıkışları kredi büyüme oranındaki kayda değer azalışa önemli katkı sağlamıştır (Grafik 7).

Grafik 7: Kredi/GSYiH Açığı ve Toplam Kredi Büyüme Oranı: 2010-2017

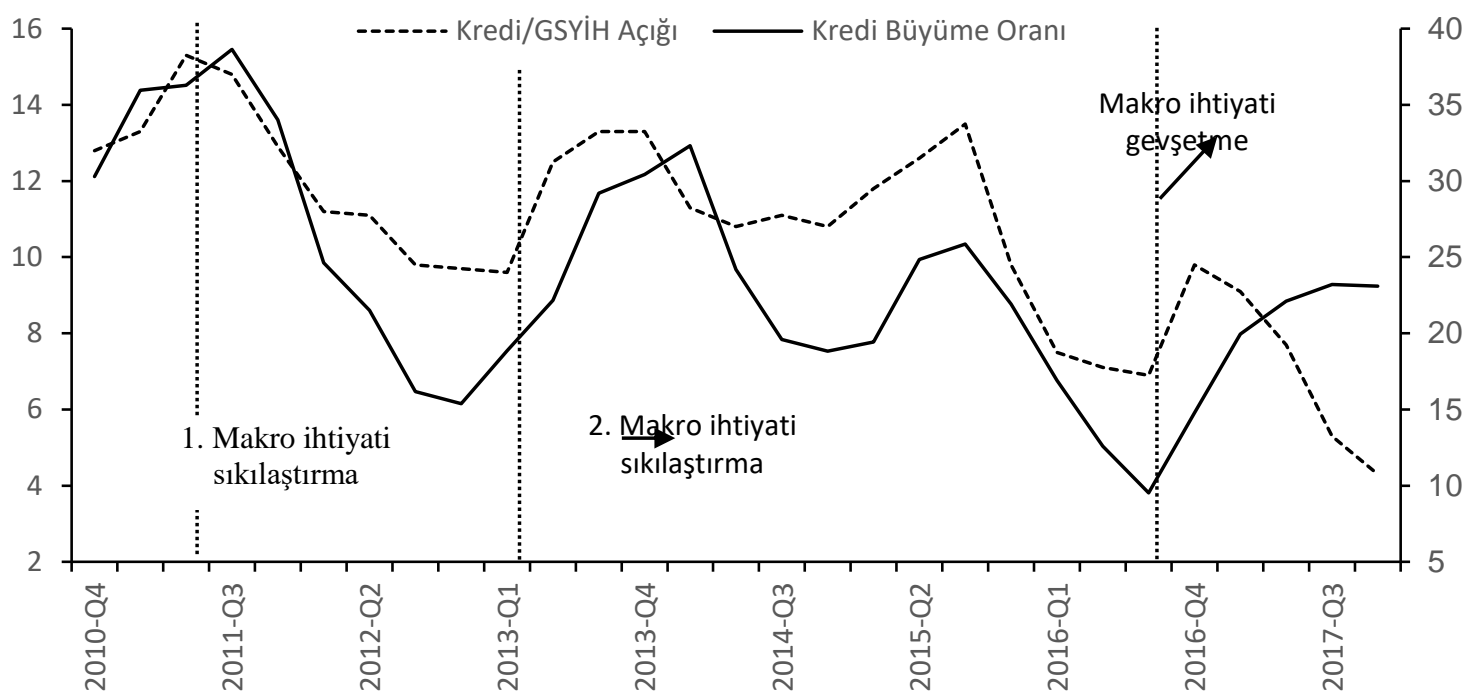

Not: Sol eksen kredi/GSYiH açığını, sağ eksen ise kredi büyüme oranını göstermektedir. Kaynak: TCMB

2012 yılının ortalarından itibaren artan sermaye girişleri ve düşük seyreden kredi faizlerinin yanı sıra ilk sıkılaştırma paketinin de etkisinin giderek azalması, 2012 yılının son çeyreğinden itibaren kredi hacminin yeniden genişlemeye başlamasına yol açmıştır. Kredi büyüme hızının yaklaşık bir yıl içerisinde \%15'lerden \%30'lara ulaşması karşısında 2013 yılının son çeyreğinden itibaren mevcut makro ihtiyati tedbirler daha da sıkılaştırılmış ve tanımlanan yeni araçlarla desteklenmiştir.

Kredi büyümesinde, makro intiyati sıkılaştırma paketlerinin etkisiyle girilen azalış trendi FED'in parasal sıkılaştırmaya başlaması ile birlikte güçlenerek devam etmiştir. Bununla birlikte söz konusu dönemde yaşanan bir dizi olumsuz iç ve dış şokun kredi büyüme oranını makul kabul edilebilecek düzeyin ${ }^{12}$ altına sürüklemesi neticesinde Eylül $2016^{\prime}$ da makro intiyati politika duruşu değiştirilmiştir. Kredi büyümesini sınırlamaya yönelik yürürlükte olan çok sayıda düzenleme gevşetilmiş veya yürürlükten kaldırılmıştır. Tüketici kredilerine yönelik makro intiyati politika duruşunun gevşetilmesi ve 2017 yılından itibaren ticari kredileri desteklemeye yönelik KGF kefalet teşviklerinin arttırılmasıyla kredi büyümesinde yeniden toparlanma gerçekleşmiştir.

BIS'e (2017) göre kredi/GSYiH açığının \%10'u aşması bankacılık sektörü açısından sorun teşkil etmektedir. Geçmişte yaşanan bankacılık krizlerinin üçte ikisinde, açığın kriz öncesindeki üç yıl boyunca bu eşik değerin üzerinde gerçekleştiği tespit edilmiştir. Grafik 7'de, Türkiye'deki kredi/GSYiH açığının bazı dönemlerde tehlikeli sayılabilecek noktalara ulaştığı görülmektedir. Bununla birlikte son dönemde GSYiH'de yaşanan artış ve kredi büyüme hızının makul seviyelere çekilmesi, söz konusu açığın giderek kapanmasına katkı sağlamıştır. 
Grafik 8. Tüketici Kredileri ve Bireysel Kredi Kartları Büyüme Oranı: Kasım 2010-Aralık 2017

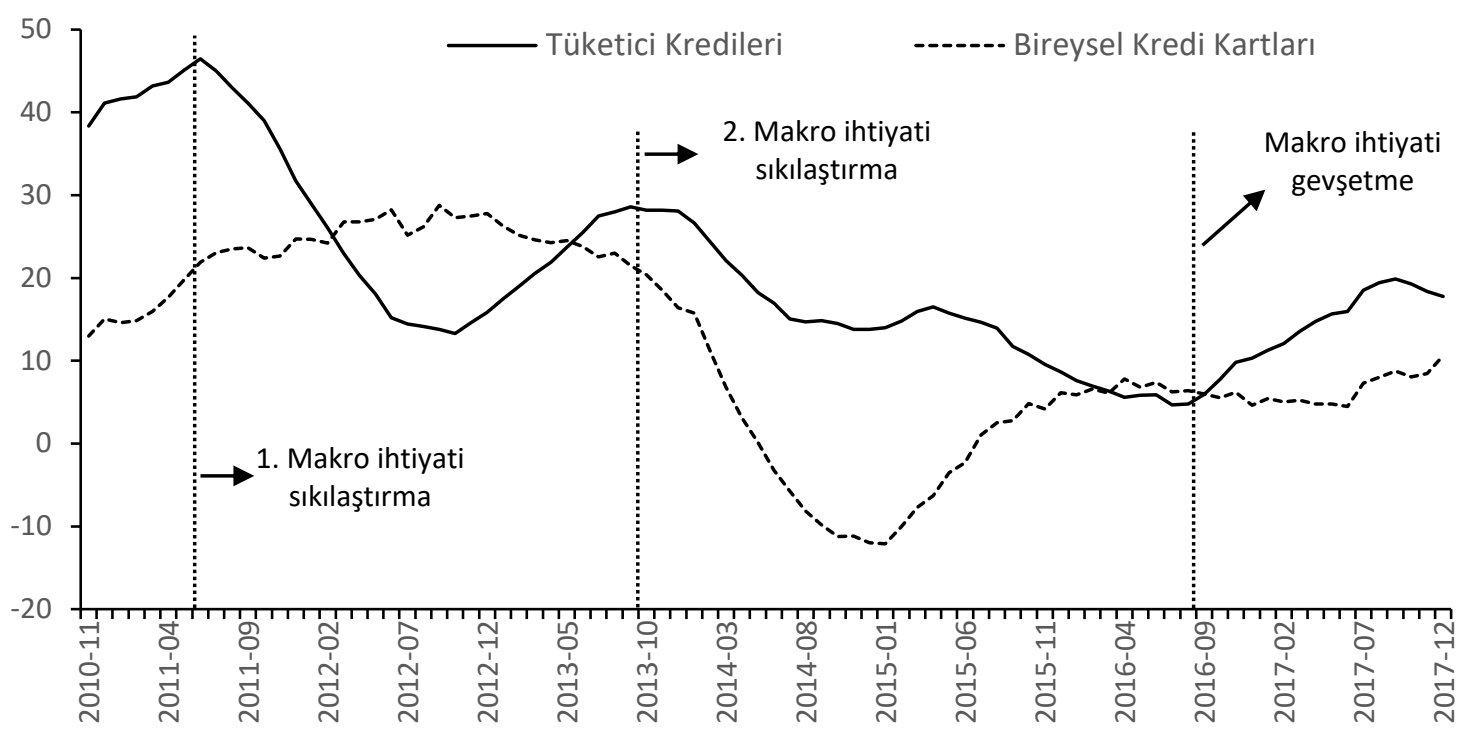

Not: Değişkenler öncelikle mevsimsellikten arındırılmış ardından yıllık yüzde değişimleri hesaplanmıştır. Kaynak: BDDK

Türkiye'de kredi büyümesini doğrudan sınırlamaya yönelik makro ihtiyati tedbirlerde ticari kredilerden ziyade tüketici kredileri ve hanehalkı borçluluğunun sınırlandırılmasına odaklanılmıştır. Grafik 8'den tüketici kredileri ve bireysel kredi kartları büyüme oranlarının seyri izlendiğinde, makro ihtiyati tedbirlerin etkin bir şekilde çalıştığı görülmektedir. Makro ihtiyati sıkılaştırma paketleri uygulamaya konulduktan sonra tüketici kredilerinin büyüme oranlarında kayda değer bir düşüş eğilimi gözlenmektedir. Bireysel kredi kartlarının ilk sıkılaştırma paketinden etkilenmemesinin sebebi ise söz konusu pakette bireysel kredi kartlarına yönelik bir düzenlemenin bulunmamasıdır. Bununla birlikte ikinci makro intiyati sıkılaştırma paketinin ardından bireysel kredi kartları büyüme oranında da aşağı yönlü ciddi bir kırılma gerçekleşmiştir.

\subsection{Dış Borç Üzerindeki Etkiler}

Türkiye'de sermaye girişlerinin kredi büyümesini hızlandırıcı etkisinin güçlenmesinde, bankaların finansal olmayan kuruluşlara vermiş oldukları kredilerdeki artışın önemli rol oynadığı görülmektedir. Haziran 2009 ' daki düzenleme ${ }^{13}$ ile döviz kazancı olmayan şirketlere döviz kredisi verebilme olanağı sağlanan bankalar, kredi finansmanında ağırlıklı olarak döviz cinsinden toptan fonlamaya (wholesale funding) yönelmiştir. Düşük tasarruf oranlarına bağlı olarak mevduat dışı kaynak kullanımının artması neticesinde bir taraftan dış borç miktarı yükselirken diğer taraftan da dış borcun yükü finansal olmayan kuruluşlardan bankalara doğru kaymıştır (Grafik 9).

Grafik 10'dan da görüleceği üzere sermaye girişlerinin yoğunlaştığı dönemlerde finansal kuruluşların dış borç büyüme oranı \%30'ların üzerine çıkmıştır. Buna paralel olarak şirketlerin TL ve YP yükümlülükleri kayda değer biçimde artmıştır. 2007'de \%30 olan finansal olmayan kuruluşların yükümlülüklerinin GSYiH'ye oranı 2015 'de $\% 60$ 'a ulaşmıştır. Bununla birlikte şirketlerin yükümlülüklerinin yarısının YP cinsinden olması muhtemel kur şoklarına bağlı olarak borcu döndürme (rollover) riskini ve buna bağlı olarak da bankaların kredi riskini daha da yükseltmiştir (IMF, 2017: 68) 
Grafik 9: Brüt Dış Borç Stoku: 2010-2017 (GSYiH’ye Oranı)

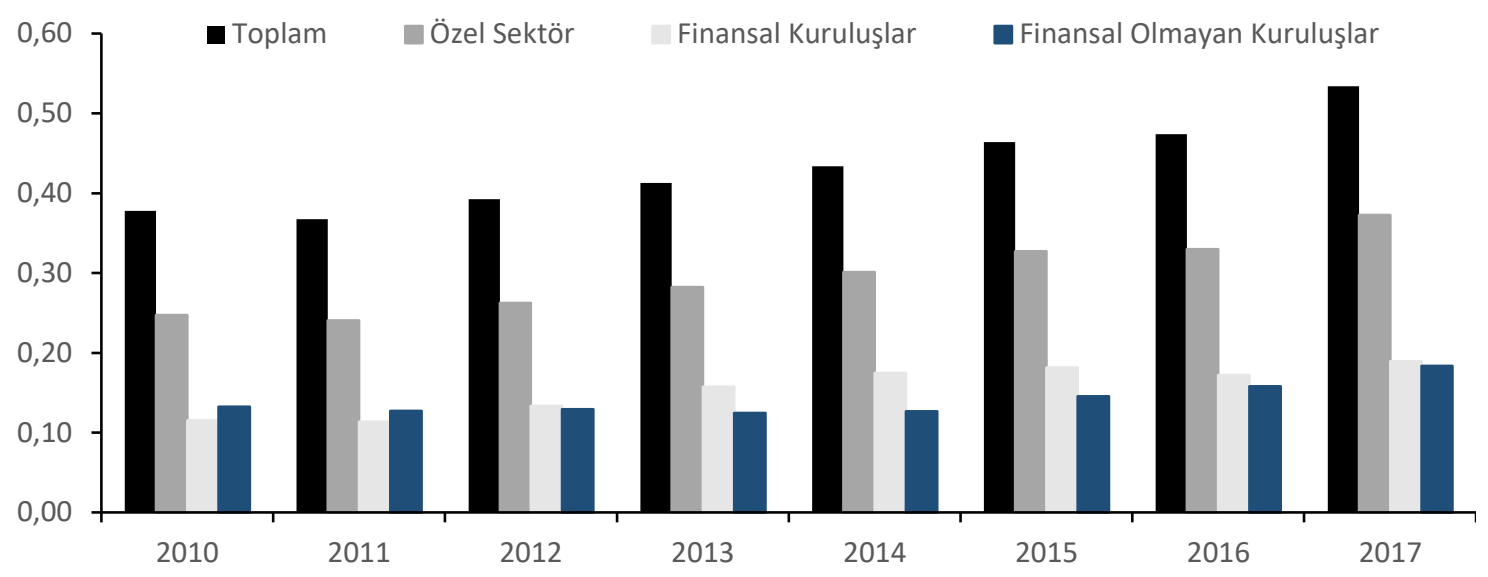

Kaynak: TCMB

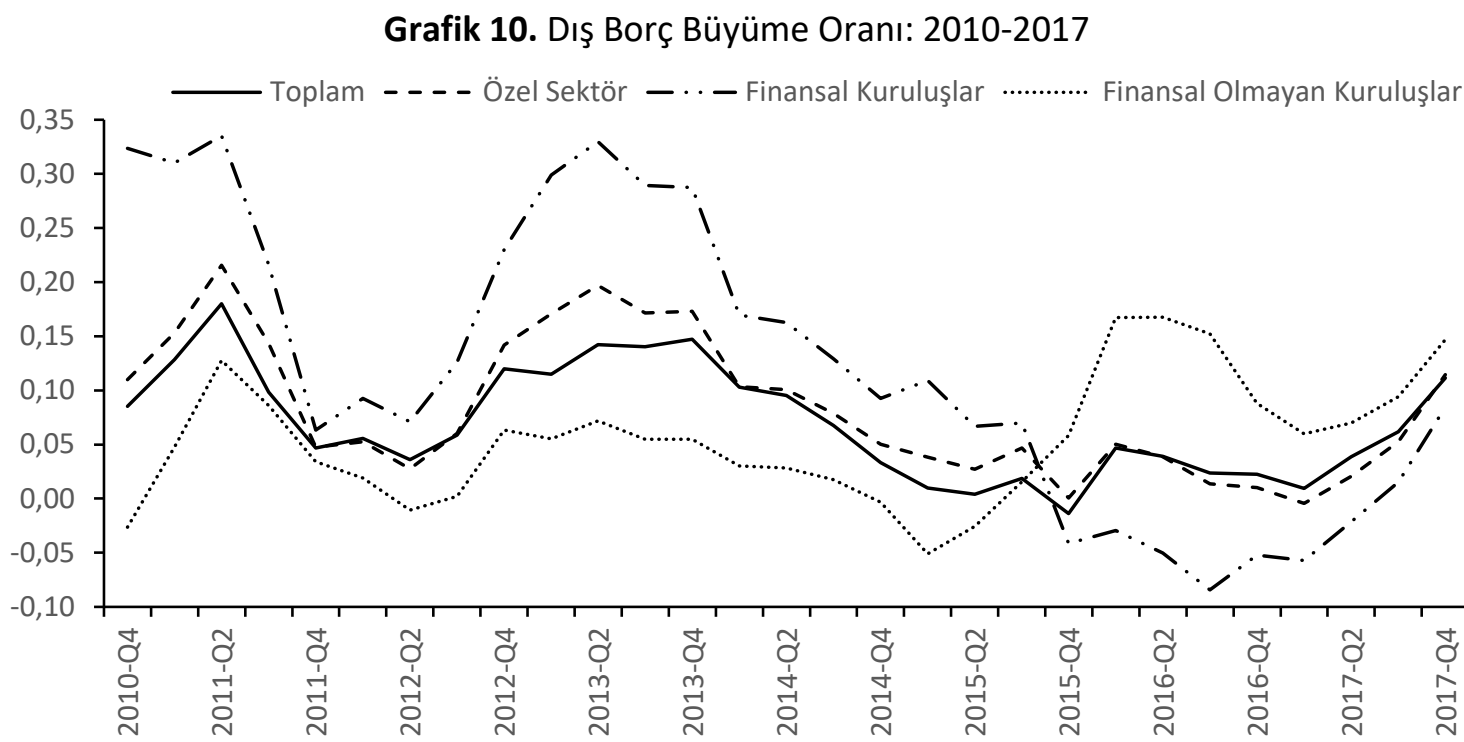

Kaynak: TCMB

Artan dış borç yükünün beraberinde getirdiği finansal riskler karşısında alınan tedbirlerin yeterli olduğunu ifade etmek güçtür. Takip edilen makro ihtiyati politika stratejisinde, özel sektör borçluluğunun ve ticari kredi büyümesinin kontrolü ikinci planda kalmıştır. Bu dönemde, özel sektör borçluluğunu sınırlamaya yönelik doğrudan bir tedbir alınmadığı gibi yeni politika bileşiminden önce yürürlükte bulunan düzenlemelerde de bir değişikliğe gidilmemiştir. Bu bağlamda, söz konusu tercihin bir bakıma politika otoritelerinin büyüme önceliklerinin getirmiş olduğu eylemsizlik yönündeki sapmayı (inaction bias) ${ }^{14}$ yansıttığını ifade etmek mümkündür.

\subsection{Rezervler Üzerindeki Etkiler}

Gourinchas ve Obstfeld'e (2012) göre gelişmekte olan bir ülkenin döviz rezervlerinin düzeyi, istatistiki ve ekonomik açıdan finansal krizin meydana gelme olasılığını belirleyen anlamlı bir faktördür. Küresel likidite bolluğunun yaşandığı dönemlerde döviz rezervlerinin güçlendirilmesi konjonktürün tersine döndüğü dönemlerde kullanılabilecek tamponlar oluşturmaktadır. Yeni politika bileşiminde kullanılan ROM, sermaye hareketlerinin yol açabileceği makro-finansal riskleri sınırlamadaki otomatik dengeleyici rolünün yanı sıra 
brüt döviz ve altın rezervlerinin "iyi” zamanlarda güçlendirilmesine de katkı sağlamıştır. TCMB'nin brüt döviz ve altın rezervlerinin seyri Grafik 11'de gösterilmektedir.

Grafik 11. TCMB Brüt Döviz ve Altın Rezervleri: Kasım 2010-Aralık 2017

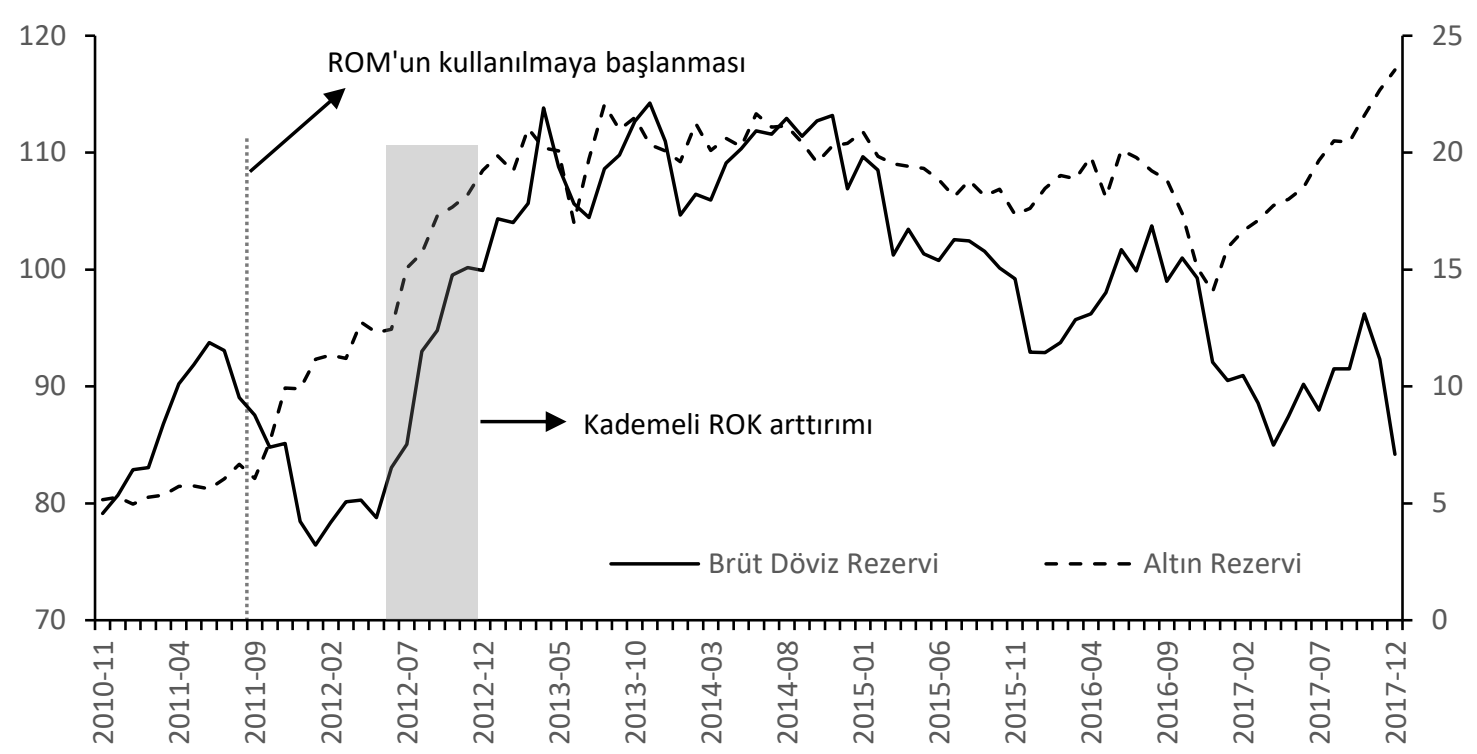

Not: Sol eksen brüt döviz rezervlerini, sağ eksen ise altın rezervlerini göstermektedir. Değerler milyar dolar cinsindendir.

Kaynak: TCMB

ROM, Eylül 2011'de tanımlanmasına karşın Euro borç krizinin etkisiyle gerçekleşen yoğun sermaye çıkışlarından dolayı ilk başlarda brüt döviz rezervleri üzerinde beklenen etkiyi yapamamıştır. Küresel risk iştahındaki iyileşmelere paralel olarak ROK' un kademeli olarak arttırıldığı Haziran-Aralık 2012 döneminde ise brüt döviz rezervleri hızla yükselmiştir. Takip eden dönemlerde ulaşılan rezerv miktarı ROK'larda gerçekleştirilen teknik ayarlamalarla muhafaza edilmeye çalışılsa da 2015 yılından itibaren sıkılaşan küresel likidite koşulları ve olumsuz şoklara bağlı olarak gerçekleşen sermaye çıkışları ile ciddi bir düşüş göstermiştir.

\subsection{Bankacılık Sektörü Üzerindeki Etkiler}

Para politikası ve makro ihtiyati politika uygulamalarının bankacılık sektörü üzerindeki etkilerine bakıldığında, sağlamlık açısından bilanço rakamlarının yüksek risk teşkil etmediği görülmektedir (Tablo 1). Sektörün sermaye yeterlilik oranı dönem boyunca yasal sınırın üzerinde seyretmiştir. Yaşanan düşüşlerde yüksek kredi büyüme hızının yanı sıra genel karşılıkların ve tüketici kredilerindeki risk ağırlıklarının arttırımasının etkisini de göz ardı etmemek gerekmektedir. Bu bağlamda sektörün kredi hacmindeki genişlemelere bağıı olarak risk ağılıklı aktiflerde gerçekleşen artışı dengelemeye yetecek özkaynak düzeyine sahip olduğunu ifade etmek mümkündür.

Kredi büyüme hızının kontrol altına alınması ile birlikte kredilerin toplam aktifler içerisindeki payındaki artış da yavaşlamıştır. Kredi büyümesinin finansmanında ise -düşük tasarruf oranlarının doğal bir sonucu olarak- mevduat dışı kaynakların payının hızlı bir şekilde arttığı görülmektedir. 2010'da \%82,8 olan kredi-mevduat oranı 2017 yılında \%120,9'a kadar yükselmiştir. TL ve YP cinsinden çekirdek dışı yükümlülüklere uygulanan zorunlu karşılık oranları ile söz konusu orandaki keskin artışlar kontrol altına alınsa da yüksek seyir devam etmiştir.

Kredi-mevduat oranındaki artış bankaların likidite pozisyonlarını da olumsuz etkilemiştir. 2010'da \%32,8 olan likit aktiflerin toplam aktiflere oranı 2017 'de $\% 24,3$ 'e gerilemiştir. 2010 'da $\% 54,7$ olan likit aktiflerin kısa vadeli yükümlülüklere oranı ise 2017 ' de $\% 44,8$ olmuştur. Bununla birlikte yeni bir makro ihtiyati araç olan ve likidite riskini temsil eden likidite karşılama oranı, sektörün kısa vadeli şoklar karşısında sağlam 
bir görünüme sahip olduğuna işaret etmektedir. Kasım 2017 itibariyle \%125 olan toplam likidite karşılama oranı yasal sınırların ${ }^{15}$ oldukça üzerinde seyretmektedir (TCMB, 2017b: 47). Sektörün likidite riskinin sınırlandırılmasında, ROM ve zorunlu karşılık uygulamalarının yanı sıra menkul kıymet portföyünün banka bilançolarında önemli yer tutmasının etkili olduğunu ifade etmek mümkündür (TCMB, 2018b: 54).

Tablo 1. Bankacılık Sektörüne ilişkin Seçilmiş Bilanço Oranları: 2010-2017

\begin{tabular}{|c|c|c|c|c|c|c|c|c|}
\hline & 2010 & 2011 & 2012 & 2013 & 2014 & 2015 & 2016 & 2017 \\
\hline Sermaye Yeterliliği ${ }^{a}$ & 19,2 & 16,7 & 18,1 & 15,4 & 16,4 & 15,6 & 15,5 & 16,8 \\
\hline $\begin{array}{l}\text { Toplam Krediler ve Alacaklar/Toplam } \\
\text { Aktifler }\end{array}$ & 52,9 & 57,2 & 59,2 & 62,1 & 64,1 & 65,2 & 66,1 & 66,9 \\
\hline Toplam Krediler/Toplam Mevduatlar & 82,8 & 95,0 & 99,9 & 107,7 & 114,4 & 116,6 & 117,3 & 120,9 \\
\hline Takipteki Krediler/Toplam Krediler & 3,7 & 2,7 & 2,9 & 2,7 & 2,8 & 3,1 & 3,2 & 2,9 \\
\hline Likit Aktifler/Toplam Aktifler & 32,8 & 30,9 & 31,3 & 28,5 & 27,6 & 26,3 & 25,1 & 24,3 \\
\hline $\begin{array}{l}\text { Likit Aktifler/Kısa Vadeli } \\
\text { Yükümlülükler }\end{array}$ & 54,7 & 53,4 & 56,6 & 54,1 & 52,9 & 50,6 & 47,4 & 44,8 \\
\hline Net Dönem Karı/Toplam Aktifler & 2,4 & 1,8 & 1,8 & 1,6 & 1,4 & 1,2 & 1,5 & 1,7 \\
\hline
\end{tabular}

a. [Özkaynaklar / (Kredi + piyasa + operasyonel riske esas tutar)]

Kaynak: (TBB, 2018).

\section{Yeni Politika Bileşimi ve Fiyat İstikrarı}

Yeni politika bileşiminin en çok eleştirildiği konuların başında fiyat istikrarının sağlanamaması gelmektedir (Kara, 2012; Özatay, 2014, Gürkaynak, Kantur, Taş ve Yıldırım-Karaman 2015; Yeldan ve Ünüvar, 2016; Özdemir, 2017; IMF, 2018). Grafik 12'den de görüleceği üzere söz konusu dönemde enflasyon oranları hedeflerin üzerinde gerçekleşmiş ve çift haneli rakamlara kadar yükselmiştir. Enflasyon oranlarında gelinen nokta, yeni politika bileşiminin fiyat istikrarı konusunda finansal istikrar kadar başarılı olamadığını net bir şekilde ortaya koymaktadır.

Grafik 12. Hedeflenen ve Gerçekleşen Enflasyon Oranları: 2010-2017

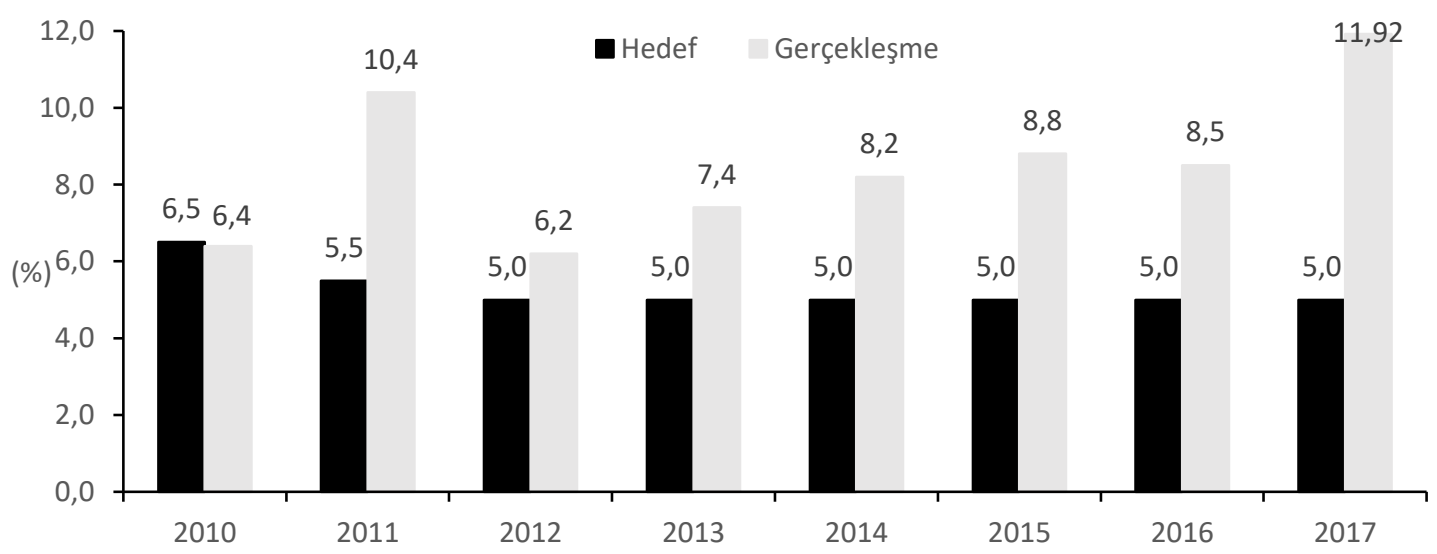

Kaynak: TCMB 
Enflasyon hedeflerine ulaşılamamasını, bekleyişlerin sağlıklı bir şekilde çapalanamaması ve parasal aktarım mekanizmalarının işleyişinin bozulması ile açıklamak mümkündür. Bu durumun gerçekleşmesine yol açan faktörlerden biri ise para politikasının yeterince sıkı olmamasıdır (IMF, 2017: 65). Küresel likidite bolluğunun beraberinde getirdiği makro-finansal riskler karşısında TCMB'nin faiz kararlarında fiyat istikrarından ziyade finansal istikrar kaygılarıyla hareket etmesi, reel faizlerin çoğu zaman negatif ve enflasyondaki yükselişi kontrol altına almaktan uzak bir seyir izlemesine neden olmuştur. Buna döviz kurunun yüksek geçiş etkisinin (pass-through) de eklenmesiyle enflasyon oranları -özellikle son dönemlerde- giderek yükselmiştir. Grafik 13 'den de görüleceği üzere "taper talk" açıklaması ile döviz kurunda başlayan sert değer kayıpları, fiyatlara büyük ölçüde yansımıştır. Kara, Öğünç ve Sarıkaya (2017) tarafından yapılan çalışmada, 2015 yılında \%8,8 olarak gerçekleşen enflasyonda döviz kurunun payının 4 puan olduğu sonucuna ulaşılmıştır. ${ }^{16}$

Grafik 13. Reel Efektif Döviz Kuru: Kasım 2010-Aralık 2017

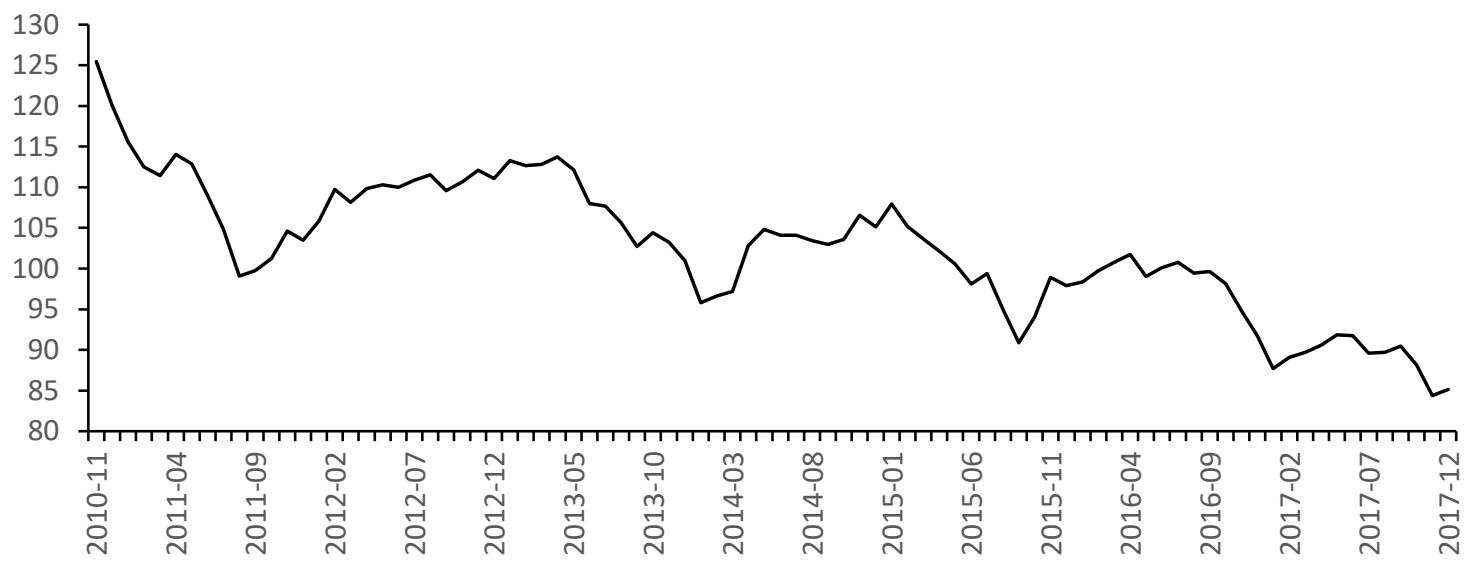

Not: TÜFE Bazlı 2003=100

Kaynak: TCMB

Finansal istikrara verilen önemin arttırıldığı ve araç setinin genişletildiği geleneksel olmayan para politikası çerçevesi, bekleyişlerin çapalanmasına ve aktarım mekanizmalarının etkinliğine zarar veren bir diğer faktör olmuştur. Fonlamanın farklı faiz oranlarından gerçekleştirilmesi fiyatlama kararlarında politika faizinin referans olma özelliğini kaybetmesine yol açmıştır. Buna bağlı olarak politika faizi ile piyasa faizleri arasındaki farkın açılmasının yanında belirsizliklerin de artması parasal aktarım mekanizmalarının işleyişini sekteye uğratmıştır. Çok araçtan ve çok sayıda faizden oluşan karmaşık para politikası çerçevesi, kamuoyu ile iletişimi ve öngörülebilirliği güçleştirmiştir. Tüm bunlara enflasyon hedeflerinin mütemadiyen tutturulamaması da eklenince kredibilite daha da düşmüş ve bekleyişlerin çapalanması daha da zorlaşmıştır.

Ağustos $2015^{\prime}$ de para politikasının operasyonel çerçevesinin sadeleştirileceğinin ilan edilmesine karşın gerçekleşen bir dizi iç ve dış şok normalleşme sürecinin yarıda kalmasına neden olmuştur. 2016 yılının son çeyreğinden itibaren döviz kurunda gerçekleşen sert değer kayıplarının enflasyona ilişkin yukarı yönlü riskleri arttırması karşısında TCMB, büyüme kaygılarının da şekillendirdiği bir politika izlemiştir. Bu doğrultuda 2017 yılının başından itibaren fonlama GLP üzerinden yapılmaya başlanmıştır. Ancak bu hamle zaten karmaşık olan operasyonel çerçeveyi daha da karmaşık hale getirmiştir. Politika faizi ile AOFM arasındaki farkın daha da yükselmesi politika faizini işlevsizleştirmiş ve enflasyon oranı son 15 yılın en yüksek yılsonu düzeyine ulaşmıştır.

\section{Sonuç}

Küresel finansal krizin ardından Türkiye gibi pek çok yükselen piyasa ekonomisinin fiyat istikrarı ile finansal istikrarın bir arada alınmasına imkan verecek politika çerçeveleri geliştirdiği görülmüştür. Gerek ortodoks enflasyon hedeflemesinin kriz ile gün yüzüne çıkan sorunları gerekse küresel sermaye akımlarındaki 
yön değiştirmelere esnek bir biçimde tepki verme gereği karşısında TCMB Kasım 2010'dan itibaren yeni politika bileşimini uygulamaya başlamıştır.

Türkiye'de, yeni politika bileşimi çerçevesinde finansal istikrarı sağlama amacıyla uygulamaya konulan politikaların başarılı bir performans gösterdiği görülmektedir. Asimetrik faiz koridoru ile yaratılan yapıcı belirsizlik ve ROM'un otomatik dengeleyici fonksiyonu, yoğun sermaye girişlerini yavaşlatmada etkili olurken zorunlu karşılıkların konjonktür karşıtı bir şekilde ayarlanması, kısa vadeli kaynak kullanımını frenlemiş ve vade uyumsuzluğunu azaltmıştır. Bununla birlikte BDDK'nın dış finansman ihtiyacını sınırlandıran makro ihtiyati tedbirleri ve küresel finansal piyasalardaki gelişmeler de iç ve dış talep arasındaki dengelenmeye katkı sağlamıştır.

Kredi büyümesini sınırlama amacıyla zorunlu karşılıklar üzerinden verilen ilk politika tepkilerinin beklentilerin altında kalmasının ardından uygulamaya konulan makro ihtiyati sıkılaştırma paketleri ile birlikte -tüketici kredileri ve bireysel kredi kartları başta olmak üzere- kredi büyüme oranlarında aşağı yönlü ciddi kırılmalar gerçekleşmiştir. Sıkılaştırııı makro ihtiyati tedbirlerle kredi büyümesinde girilen azalış trendi, TCMB'nin zorunlu karşılık oranlarını farklılaştırması ve konjonktür karşıtı bir şekilde ayarlaması ile desteklenmiştir. Bu bağlamda, yeni politika bileşiminde uygulanan makro ihtiyati politikaların, -her ne kadar küresel piyasalarda yaşanan gelişmelerden de destek bulsa da- kredi büyümesindeki aşırılıkları sınırlamaya önemli katkılar sağladığını ifade etmek mümkündür.

Makro ihtiyati politikaların finansal istikrara katkısı belirlenen ara hedefler ile sınırlı kalmamıştır. Sermaye hareketlerinin yol açabileceği makro-finansal riskleri sınırlamada otomatik dengeleyici olarak kullanılan ROM, brüt döviz ve altın rezervlerinin "iyi" zamanlarda güçlendirilmesine de katkı sağlamıştır. Bununla birlikte, mevcut mikro ihtiyati araçların Basel III çerçevesinde tanımlanan yeni makro ihtiyati araçlarla desteklenmesi, muhtemel şoklar karşısında bankacılık sektörünün dayanıklılığını arttırmıştır.

Yeni politika bileşiminin, fiyat istikrarının sağlanmasında finansal istikrar kadar başarılı olamadığı açıktır. Bu dönemde, finansal istikrar kaygılarının etkisi altında belirlenen para politikası duruşunun yeterince sıkı olmaması, reel faizlerin çoğu zaman negatif ve enflasyondaki yükselişi kontrol altına almaktan uzak bir seyir izlemesine neden olmuştur. Daha da önemlisi, para politikası ve makro ihtiyati politikanın birlikte yürütülmesi para politikasının etkinlik açısından erozyona uğramasına yol açmıştır. Finansal istikrar amacına yönelik alınan faiz kararları, enflasyon bekleyişlerinin çapalanamamasına neden olurken aktarım mekanizmalarının işleyişinin bozulması fiyat istikrarı hedefinden uzaklaşılmasına neden olmuştur. Bu bağlamda yeni politika bileşiminin finansal istikrarın sağlanmasında gösterdiği başarının, politika otoritelerinin -tek haneli faiz oranlarının kalıcı hale gelmesi ve büyümenin sürdürülmesi amacıyla- yeni politika bileşiminin içsel risklerini göz ardı etmelerine ve para politikasının normalleşmesi için atılması gereken adımları geciktirmelerine neden olduğu belirtilmelidir.

Türkiye'deki makro ihtiyati politika duruşunun büyüme kaygılarını bünyesinde barındırdığını ifade etmek gerekmektedir. Özel sektör borçluluğuna ve ticari kredilere yönelik doğrudan bir tedbir alınmamasının yanı sıra iç talep tam anlamıyla ılımlaştııılamadan makro ihtiyati tedbirlerin gevşetilmesi söz konusu kaygıların bir sonucudur. Söz konusu dönemde makro ihtiyati politikalar, -makro-finansal istikrarı sağlamaya yönelik alet çantası içinde gerekli olan konumundan bağımsız olarak- finansal döngünün (financial cycle) yanı sıra geleneksel konjonktürel döngünün (business cycle) yönetilmesinde de kullanılmıştır. Yeni politika bileşimi başarılı olmasına rağmen makro ihtiyati politikaların büyüme amacı için de kullanımı, yükselen enflasyon oranı ve küresel politika ortamının farklılaşması nedeniyle büyümenin istikrarsız bir seyir izlemesine bağı olarak politika açmazları doğurmuştur. Bu haliyle yeni politika bileşiminin kendi başarısının kurbanı (victim of its own success) olduğunu belirtmek gerekmektedir. 


\section{Son Notlar}

1. Bu çalışma, Bursa Uludağ Üniversitesi Sosyal Bilimler Enstitüsü iktisat Anabilim Dalı'nda Doç. Dr. Metin Özdemir danışmanlığında Ali ilhan tarafından hazırlanan "Finansal Istikrarı Sağlamaya Yönelik Makro ihtiyati Politikalar: Türkiye Örneği" başlıklı doktora tezinden üretilmiştir.

2. TCMB yetkililerinin açıklamaları, yeni politika bileşiminin tam olarak Kasım 2010'da uygulanmaya başladığını işaret etmektedir (Özatay, 2011: 31).

3. Faiz koridoru, enflasyon hedeflemesinin ortodoks halinde piyasa faizlerinin politika faizine yakın bir yerde oluşmasının sağlamak amacıyla kullanılmaktadır. Geleneksel uygulamada pasif bir role sahip olan faiz koridoru, politika faizi etrafında dar ve simetrik bir bant şeklinde tanımlanmaktadır. Yeni çerçevede faiz koridoru, kısa vadeli faizlerin öngörülebilirliğine ve koridorun genişliğine bağlı olarak yaratılan belirsizlik ile aktif bir politika aracına dönüştürülmüştür. Parasal duruşa "ince ayar" yapma olanağı sağlayan faiz koridoru ile para politikasının küresel ekonomideki belirsizlikler ve risk iştahındaki değişmeler karşısındaki esnekliğinin artırılması hedeflenmiştir (TCMB, 2012a: 91; Kara 2012: 18).

4. ROM, bankaların TL cinsinden zorunlu karşılıklarının belirli bir yüzdesini döviz veya standart altın olarak tutabilmelerine olanak sağlayan bir uygulamadır. TCMB'nin zorunlu karşılıklar çerçevesinde geliştirdiği konjonktür karşıtı yeni bir makro ihtiyati araç olan ROM ile sermaye hareketlerindeki dalgalanmaların döviz kuru ve finansal piyasalar üzerindeki etkilerinin yumuşatılması, bankaların likidite yönetimlerine esneklik kazandırılması ve döviz rezervlerinin güçlendirilmesi hedeflenmiştir (Ermişoğlu, Oduncu ve Akçelik, 2013: 2).

5. Cari açığın finansmanının iyileştirilmesi ve kredi büyüme hızını kontrol altına alınması şeklinde tanımlanan ara hedeflere, "dış finansal şoklara karşı güvenlik ağlarının desteklenmesi" ve "sınır ötesi sermaye akımlarının tetiklediği finansal genişleme (financial amplification) mekanizmalarının ılımlaştırılmasını" üçüncü ve dördüncü ara hedefler olarak ilave etmek mümkündür (Kara, 2015).

6. FED guvernörü B. Bernanke'nin niceliksel genişleme programının kademeli olarak sonlandırılacağına ilişkin sinyaller verdiği konuşması "taper talk" olarak adlandırılmaktadır (Aktaş, Erduman ve Kaya Ekşi, 2018).

7. Merkezinde bulaşma (contagion) olgusunun bulunduğu kesit boyutundaki sistemik risk, finansal kurumlar ve piyasalar arasındaki karşılıklı bağlantılar sonucunda meydana gelmektedir. Belirli bir zamanda, finansal kurumların veya piyasaların maruz kaldıkları şoklar, karşılıklı bağlantılar vasıtasıla güçlenmekte ve sistemin geneline yayılabilmektedir (Claessens, Ghosh ve Mihet, 2013: 161; Frait ve Komarkova, 2011: 100).

8. TCMB, faiz ödemelerinde [(mevduat+özkaynak)/kredi] oranını fonlama kalitesinin ölçütü olarak belirlemiştir. Buna göre söz konusu oranın sektör ortalaması üzerinde olması halinde ilgili finansal kuruluşa daha yüksek faiz ödemesi yapılmaktadır (TCMB, 2014b: 42).

9. Yeni politika bileşimi öncesinde de var olan GLP uygulaması, 1990'dan itibaren sadece 7 defa kullanılmıştır.

10. Küçük ve orta boy işletmelerin (KOBi) finansmanına yardımcı olmak amacıyla 1993 yılında oluşturulan KGF, Hazine destekli bir kurumsal kefalet kuruluşudur. Buna göre KGF bankalara, geri ödenmemiş kredilerin bilançolarındaki payı \%7'yi aşmadığı sürece ticari krediler için \%85, КОВi kredileri için \%90 ve ihracat kredileri için \%100 oranına kadar devlet garantisi verebilmektedir (IMF, 2018: 24).

11. Mali baskınlık problemi, kısa vadeli yüksek borç stokunun para politikasının etkinliğini kısıtlaması ve aktarım mekanizmasının işleyişi üzerinde bozucu etkilere yol açmasıdır (Kara ve Orak, 2008: 25). Dışsal baskınlık problemi ise sermaye girişlerinin aniden durmasının veya tersine dönmesinin döviz kurunda ve faiz oranlarında yüksek volatiliteye yol açarak enflasyon hedeflerine ulaşılmasını zorlaştırması ve para politikasının kredibilitesini azaltmasıdır (Fraga, Goldfajn ve Minella, 2004: 384).

12. Kara, Küçük, Tiryaki ve Yüksel (2013) tarafından gerçekleştirilen çalışmada kredi büyüme oranı için \%15 referans değerinin makul ve sağlıklı olduğu ifade edilmektedir.

13. 16 Haziran 2009'da yapılan düzenleme ile hanehalklarının döviz cinsinden borçlanmaları yasaklanırken bankaların, döviz kazancı olmayan şirketlere döviz taahhüdü olmaksızın en az 1 yıl vadeli ve 5 milyon dolar tutarlı döviz kredisi verebilme olanağı sağlanmıştır (IMF, 2010: 11).

14. Makro ihtiyati politikanın kısa vadeli maliyetlerinin görünür, uzun vadeli faydalarının ise belirsiz olmasından ötürü politika otoritelerinin müdahaleleri erteleme/geciktirme yönündeki tutumları eylemsizlik yönündeki sapma olarak adlandırılmaktadır (Brockmeijer, 2014: 167).

15. 2017 yılı için toplam likidite karşılama oranı \%90 olarak belirlenmiştir.

16. Kara vd. (2017) çalışmalarında 2006-2016 yılları arasında Türkiye'deki enflasyon dinamiklerini incelemişlerdir. Buna göre 2006-2010 yılları arasında enflasyon ortalama \%8,22 olarak gerçekleşirken bunda döviz kurunun katkısı 0,36 puan olmuştur. 2011-2016 yılları arasında ise ortalama \%8,26 olarak gerçekleşen enflasyon oranında döviz kurunun katkısı 2 puana yükselmiştir. Diğer bir ifadeyle bu dönemde döviz kurunun geçiş etkisi artmıştır. 


\section{Kaynaklar}

Aktaş, C., \& Cortuk, O. (2012). Turkey's experience with the global crisis: Restructring policies within a financial stability framework. Journal of Economic Policy Reform, 15(3), 195-205.

Aktaş, Z., Erduman, Y., \& Kaya Ekşi, N. (2018). Gelişmekte olan ülkelere yönelen portföy akımları: Pastadan kim daha fazla pay alacak?. https://tcmbblog.org/tr/gelismekte-olan-ulkelere-yonelen-portfoy-akimlari-pastadan-kimdaha-fazla-pay-alacak/ (Erişim tarihi: 24 Ocak 2019).

Başçı, E., \& Kara, H. (2011). Finansal istikrar ve para politikası. iktisat, İşletme ve Finans, 26(302), 9-25.

BIS, (2017). International banking and financial market developments. BIS Quarterly Review, September.

Brockmeijer, J. (2014). The institutional setting of macroprudential policy: Putting macroprudential policy to work. De Nederlandsche Bank Occasional Studies, 12(7), 165-177.

Claessens, S. M., Ghosh, S. R., \& Mihet, R. (2013). Macro prudential policies to mitigate financial system vulnerabilities in emerging markets. (Ed.) O. Canuto \& S. R. Ghosh, Dealing with the Challenges of Macro Financial Linkages in Emerging Markets, (ss. 155-178). Washington D. C.: World Bank

Elekdag, S., \& Wu, Y. (2011). Rapid credit growth: Boon or boom-bust? IMF Working Paper, 241.

Ermişoğlu, E., Oduncu, A., \& Akçelik, Y. (2013). Rezerv opsiyonu mekanizması ve kur oynaklığı. TCMB Ekonomi Notları, No. 2013-04.

Fraga, A., Goldfajn, I., \& Minella, A. (2004). Inflation targeting in emerging market economics. (Ed.) M. Gertler \& K. Rogoff, NBER Macroeconomics Annual Volume 18, (ss. 365-413). The MIT Press.

Frait, J., \& Komarkova, Z. (2011). Financial stability, systemic risk and macroprudential policy. Czech National Bank Financial Stability Report, No: 2010/2011, 96-111.

Gourinchas, P. O., \& Obstfeld, M. (2012). Stories of the Twentieth Century for the Twenty-First. American Economic Journal: Macroeconomics, 4(1), 226-265.

Gürkaynak, R. S., Kantur, Z. Taş, M. A., \& Yıldırım-Karaman, S. (2015). Monetary policy in Turkey after Central Bank independence. Iktisat, işletme ve Finans, 30(356), 9-38.

IMF, (2010). 2010 Article IV consultation with Turkey. IMF Country Report, No. 10/278.

IMF, (2017). Increasing resilience to large and volatile capital flows-the role of macroprudential policies. IMF Policy Paper, No. 17/260.

IMF, (2018). 2018 Article IV consultation with Turkey. IMF Country Report, No. 18/110.

Kara, A., \& Orak, M. (2008, Ekim). Enflasyon hedeflemesi. Ekonomik Tartışmalar Konferansı (Emin Öztürk Anısına).

Kara, A. H. (2012). Küresel kriz sonrası para politikası. iktisat, İşletme ve Finans, 27(315), 9-36.

Kara, H., Küçük, H., Tiryaki, S. T., \& Yüksel C. (2013). Türkiye için makul kredi büyüme oranı ne olmalı? TCMB Ekonomi Notları, No. 2013-03.

Kara, H. (2015, October). Turkey's experience with macroprudential policy, macroprudential policy: Effectiveness and implementation challenges. CBRT-IMF-BIS Joint Conference.

Kara, H. (2016). Turkey's experience with macroprudential policy. BIS Papers, 86, 123-140.

Kara, A. H., Öğünç, F., \& Sarıkaya, Ç. (2017). Inflation dynamics in Turkey: A historical accounting. CBRT Research Notes in Economics, No. 2017-03.

Mendoza, E. G., \& Terrones, M. E. (2008). An anatomy of credit booms: Evidence from macro aggregates and micro data. NBER Working Paper Series, No. 14049.

Özatay, F. (2011). Merkez Bankası'nın yeni para politikası: İki hedef-üç ara hedef-üç araç. Iktisat, işletme ve Finans, 26(302), 27-43.

Özatay, F. (2014). A note on the new monetary policy of the Central Bank of Turkey. (Ed.) A. Arı, The European Debt Crisis: Causes, Consequences, Measures and Remedies, (ss. 185-194). Newcastle: Cambridge Scholars Publishing.

Özdemir, M. (2017). Büyüme ve enflasyon: Post-truth(?). BUSiAD'dan Bakış, No. 140, Mart-Haziran, 12-20.

TBB, (2018). Türkiye'de Bankacılık Sistemi "seçilmiş rasyolar 2007-2017". Ankara.

TCMB, (2010). 2011 yılında para ve kur politikası. Ankara.

TCMB, (2011a). Finansal istikrar raporu. Sayı 12, Ankara.

TCMB, (2011b). Finansal istikrar raporu. Sayı 13, Ankara.

TCMB, (2011c). 2012 yılında para ve kur politikası. Ankara. 
TCMB, (2012a). Enflasyon raporu. No. 2012-I, Ankara.

TCMB, (2012b). 2013 yılı para ve kur politikası. Ankara.

TCMB, (2013). TCMB'nin yeni para politikası bileşimi ve 2013 yılında para ve kur politikası. TCMB Bülten, Sayı. 29, Ankara.

TCMB, (2014a). Yıllık rapor 2013. Ankara.

TCMB, (2014b). Finansal istikrar raporu, Sayı 19. Ankara.

TCMB, (2014c). 2015 yılı para ve kur politikası. Ankara.

TCMB, (2015a). Yıllık rapor 2014. Ankara.

TCMB, (2015b). Finansal istikrar raporu. Sayı 21, Ankara.

TCMB, (2016). Finansal istikrar raporu. Sayı 23, Ankara.

TCMB, (2017). Finansal istikrar raporu. Sayı 25, Ankara.

TCMB, (2018). Finansal istikrar raporu. Sayı 26, Ankara.

Yeldan, A. E., \& Ünüvar, B. (2016). An assessment of the Turkish Economy in the AKP Era. Research and Policy on Turkey, $1(1), 11-28$. 